\title{
Operational interactions between sea lion species (Otariinae) and commercial fisheries
}

\author{
Karina Lopes Ramos ${ }^{1}$, Rodrigo Machado ${ }^{2}$, Alexandre Schiavetti $^{3}$
}

\begin{abstract}
Many marine mammal species, such as pinnipeds, have shown an increased frequency of interaction with fisheries. Thus, we aimed to investigate the operational interactions between commercial fishing and sea lion species of all five continents, between 1982 and 2018. We found 130 publications in which operational interactions between commercial fisheries and the species of sea lions were detected, in 12 countries. These interactions included bycatch, presence of the animals around boats, depredation, gear damage, entanglement in lost/ discarded fishing gear, boat collisions, aggressions, gear-related injuries and harassment. Trawl and gillnet fisheries showed significantly increased association with bycatch, although purse seine fishing was reported as having the largest groups of pinnipeds in the interactions. Gillnet and line fisheries registered more events of depredation and gear damage. Other interactions, such as entanglement and aggressions, were also very common for all species. We suggest that the interactions should be monitored using the data of onboard observers from different fleets and fisheries. Bycatch limits, change in fishing practices, decreased fishing effort, and the establishment of effective MPAs may reduce impact on the fauna. Moreover, data on bycatch should be standardized to enable comparisons between fisheries and locations. The extent of commercial losses caused by pinnipeds should also be characterized to depict the real impact of operational interactions in fisheries economy. Lastly, the identification of interaction hotspots can enable efficient conflict management in the affected areas.
\end{abstract}

Keywords: Interactions; Sea Lions; Fisheries; Conflicts; Pinnipeds

\footnotetext{
1 Pesquisadora associada ao Laboratório de Etnoconservação e Áreas Protegidas/LECAP, Universidade Estadual de Santa Cruz, Rodovia Jorge Amado, km 16, Ilheus, BA, 45662-090, Brasil. Atualmente atuando como bolsista de pesquisa do Projeto GEF Mar na Reserva Extrativista Marinha do Corumbau (ICMBio), Bahia, Brasil.

2 Grupo de Estudos de Mamíferos Aquáticos do Rio Grande do Sul, Rua Machado de Assis \#1456, Osório, RS, 95520-000, Brasil. Programa de Pós-Graduação em Biologia Animal, Universidade Federal do Rio Grande do Sul, Rua Bento Gonçalves \#9500, bloco IV, prédio 43435, Porto Alegre, RS, 91501-970, Brasil. Grupo de Tecnologia e Ciência Pesqueira, Departamento de Engenharia de Pesca, Universidade do Estado de Santa Catarina, Rua Cel. Fernandes Martins \#270, Laguna, SC, 88790000, Brasil.

3 Departamento de Ciências Agrárias e Ambientais, Universidade Estadual de Santa Cruz, Rodovia Jorge Amado, km 16, Ilheus, BA, 45662-090, Brasil. Investigador Asociado ao CESIMAR/CENPAT, Puerto Madryn, Chubut, ARG.

* Corresponding author. $\triangle \mathrm{E}$-mail address: KLR (gauchaoceano@yahoo.com.br), RM (ecomachado@gmail.com), AS (aleschi@uesc.br)
} 


\section{SIGNIFICANCE STATEMENT}

This manuscript is original and it shows a review on operational interactions between commercial fisheries and sea lions worldwide, containing information on types and magnitude of interactions, as well as on the effect of mitigation of impacts in different countries and fisheries. Given that operational interactions with fisheries, such as bycatch, can be responsible for the population decline of several marine species, we consider this article is very relevant for conservation.

\section{INTRODUCTION}

Interactions between marine mammals and commercial fisheries have increased over time (DeMaster et al. 2001; Harwood 1983). One of the many factors that increase the frequency and intensity of interactions is a decline in fishery resources, which makes marine animals perceive fishing boats as an "easy" source of food (Kaschner and Pauly 2005). Since the ban on marine mammal culling imposed by many countries, some populations have been recovering from declines (Magera et al. 2013), although fish stocks and fishery catches have not followed this recovery (Myers and Worm 2003; Pauly and Zeller 2016). Additionally, fisheries have expanded to explore new areas and resources, (Swartz et al. 2010), possibly facilitating the occurrence of more interactions.

More specifically, interactions between marine mammals and commercial fisheries can be biological/trophic (indirect) or operational (direct) (Beverton 1985; Lavigne 2003). Biological interactions refer to the indirect effects of fisheries on marine animals, as in the case of competition for food resources, as they both often target the same prey (Kaschner and Pauly 2005; Plagányi and Buttenworth 2009). Operational interactions in fisheries usually occur when fishing grounds and the foraging area of marine mammals overlap and when the animals frequently come into physical contact with the fishing gear and boats. The operational interactions of fisheries have a negative effect on many populations of marine mammals. Bycatch, which is the nonintentional capture of individuals that will be later discarded dead or alive, may significantly reduce the abundance of top predators, thus altering the trophic structure and functioning of marine ecosystems (Dayton et al. 2002; Read 2008). More than $80 \%$ of marine mammal species have been captured as bycatch (Reeves et al. 2013), which makes the incidental capture of species one of the leading causes of population decline (Kovacs et al. 2012). This contact can also lead marine mammals to damage or capture and consume the fish caught by fishing gear (depredation), thus reducing the productivity and profitability of the fishery. Furthermore, the animals may be injured or killed due to entanglement in discarded/lost gear, boat collision and retaliation by fishermen (Alverson et al. 1994; Beverton 1985; Lavigne 2003; Read 2005).

Among marine mammals, pinnipeds (sea lions, fur seals, seals and walruses) belong to a group that exhibits increased levels of interactions with different fisheries (Perrin 1991; Wickens 1995). To assess direct operational interactions with fisheries, we chose this specific group of animals because some of them are endemic and endangered or near threatened and they interact with different fisheries worldwide (Wickens 1995). 
This article is part of doctoral research conducted to analyse conflicts between South American sea lions (Otaria flavescens) and gillnet fisheries, and the conservation of these animals in Marine Protected Areas (Ramos, 2018).

This paper is a review of current knowledge on the occurrence and types of operational interactions between existing sea lion species and commercial fisheries. Furthermore, we aim to identify which fisheries interact most frequently with sea lions and detect any knowledge gaps.

\section{METHODS}

\section{Species of sea lions}

This group includes sea lions (subfamily Otariinae), represented by six extant species: the South American sea lion Otaria flavescens (Shaw 1800), the New Zealand sea lion Phocarctos hookeri (Peters 1866), the Australian sea lion Neophoca cinerea
(Perón 1816), the California sea lion Zalophus californianus (Lesson 1828), the Galapagos sea lion Zalophus wollebaeki (Sivertsen 1953) and the Steller sea lion Eumetopias jubatus (Schreber 1776), with a wide distribution (Figure 1) and specific characteristics (Table 1).

\section{Data collection for operational interactions}

To describe the operational interactions between commercial fisheries and the species of sea lions, we performed a literature review of the research content of interest in the websites Science Direct, Scopus, LATINDEX, SciELO, REDALyC, Web of Science, Ingenta, the CAPES Portal of Journals and Research Gate. The keywords used for our investigation were a combination of the scientific name of each sea lion species plus each of the following keywords, separately: "interaction", "conflict", "bycatch", "predation", "depredation", "capture", "take", "overlap", "fisheries",
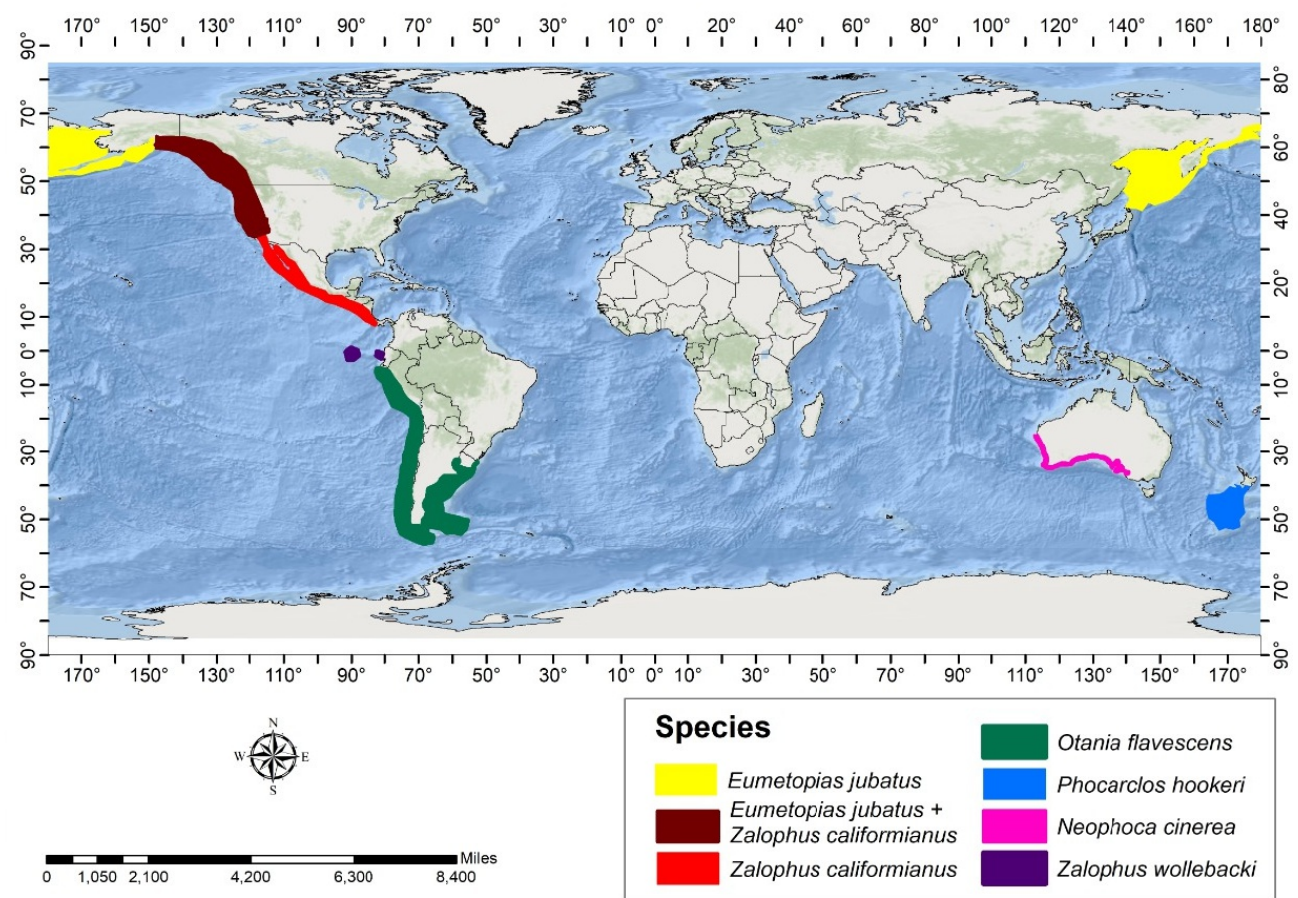

Figure 1. Map adapted from IUCN, showing the distribution of six species of sea lions in the world. 
Table 1. Geographic range, population size, population trend and conservation status of sea lion species.

\begin{tabular}{|c|c|c|c|c|c|c|}
\hline & O. flavescens & P. hookeri & N. cinerea & Z. californianus & Z. wollebaeki & E. jubatus \\
\hline Geographic range & $\begin{array}{c}\text { Northern Peru to Southern } \\
\text { Brazil }\end{array}$ & New Zealand & Australia & $\begin{array}{l}\text { Mexico to Canada; } \\
\text { Alaska }\end{array}$ & Ecuador & Japan to California \\
\hline Population size & $\geq 445.000$ & Around 9.880 & $<13.000$ & Around 387.646 & * 9.200 to 10.600 & Around 160.867 \\
\hline Population trend & Stable & Declining & Declining & Increasing & Declining & Increasing \\
\hline Conservation status & Least concern & Endangered & Endangered & Least concern & Endangered & Near threatened \\
\hline
\end{tabular}

Legend: Aurioles-Gamboa and Hernández-Camacho (2015); Cárdenas-Alayza et al. (2016); Chilvers (2015); Geschke and Chilvers (2019); Gelatt and Sweeney (2016); Goldsworthy (2015); Loughlin et al. (1984); Maniscalco et al. (2004); Trillmich (2015); Vaz-Ferreira (1981); (*) Mature individuals.

"fishing", "fishery", "marine debris" and "entanglement". The keywords were chosen according to the most common types of interactions or terms found in research on marine mammal-fishery conflicts. Only studies published from 1982 to 2018, totalling 36 years, were chosen. Before 1982, studies were much scarcer and/or more difficult to access. After each search, the studies were filtered according to their title and abstracts. Data from academic theses, dissertations, monographs and abstracts presented at conferences and congresses were not used because we chose to focus on published articles and official reports. Moreover, studies regarding the interactions in farms that cultivate marine organisms were not included since they do not involve fishing. Studies in all languages were accepted.

The selected studies were divided according to the sea lion species, countries and the different types of fishery in order to compare the impacts of the operational interactions of the different fisheries. The fisheries were split into five categories: trawl, gillnet, purse seine, line fisheries and trap. The line fisheries category included all fisheries that use lines, baited hooks and visual attractions to capture marine organisms (longline, jigging, hook and line, troll and handline). Some data could not be classified into a particular fishery because they referred to entanglement in discarded/ lost gear and other fishing-related marine debris mainly of unidentifiable origin. For the same reason, other types of interactions with fisheries (e.g. aggressions and boat collision) could not be related to a specific fishery, as they referred to stranding data. The majority of data were obtained by onboard observers and less frequently by interviews with fishermen and anecdotal reports. Some studies provided information for more than one type of fishery, but not separately. Thus, these data could not be presented separately by fishery.

\section{RESULTS}

Our search retrieved 130 studies on operational interactions for the six species of sea lion listed (Figure 2) and the five different types of fishery (Figure 3 ) identified in 12 countries (Figure 4). The species $Z$. californianus produced the most studies $(n=44)$, followed by $O$. flavescens, $P$. hookeri, E. jubatus, N. cinerea and $Z$. wollebaeki (Figure 2).

Trawl and gillnet fisheries showed significantly increased association with bycatch occurrence and numbers (Figure 5; Tables 2 to 7). Depredation and gear damage events were more common in gillnet and line fisheries (Figure 5).

This study also showed that all species are impacted by other kinds of operational interactions, such as entanglement in lost/ 
discarded fishing gear, harassment, with line fisheries, seven with trawls, five aggressions, gear-related injuries and boat with purse seines, two with traps and seven collisions (Figure 6; Tables 2 to 7 ).

\section{Otaria flavescens} From the 37 studies that depicted (9), Argentina (8), Brazil (5), Peru (1) and operational interactions with $O$. flavescens, Colombia (1).

14 described interactions with gillnets, ten

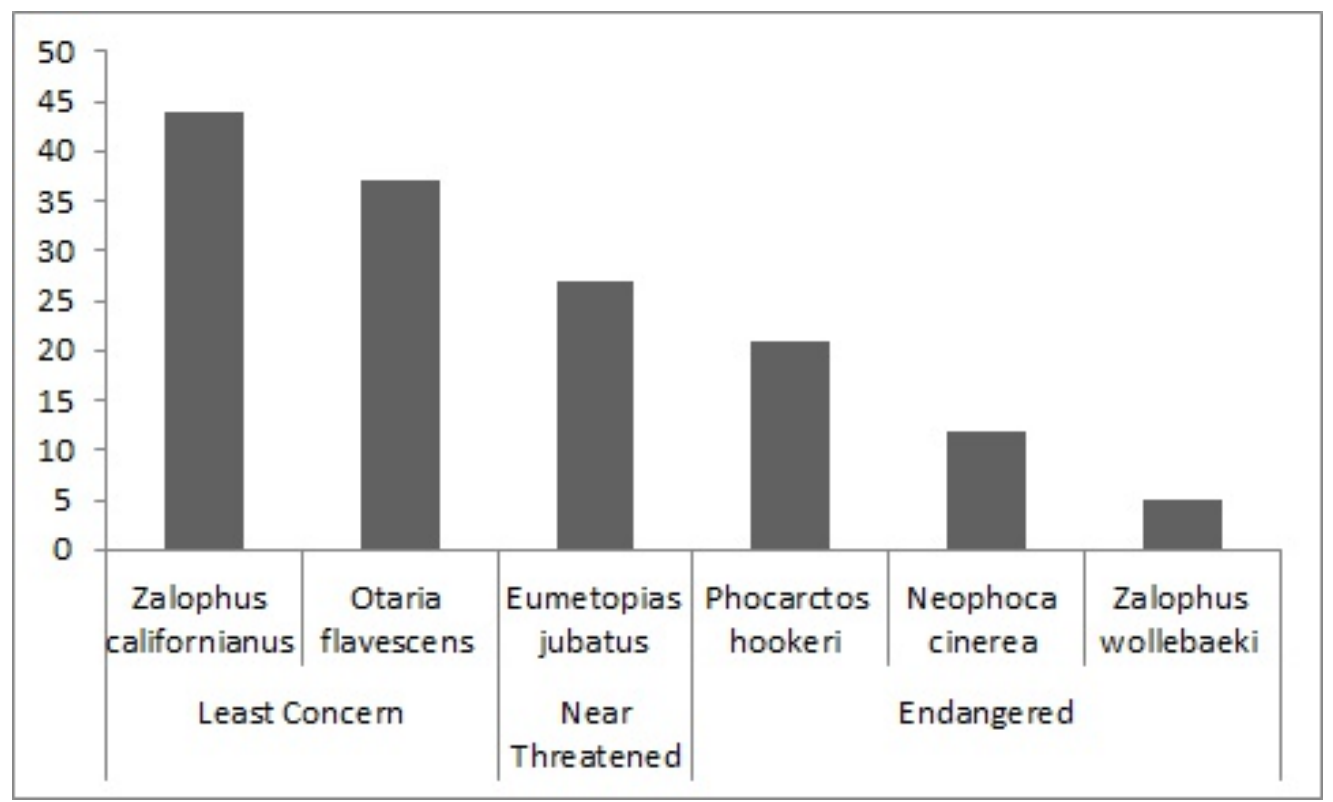

Figure 2. Number of studies on operational interactions with commercial fisheries by species of sea lions.

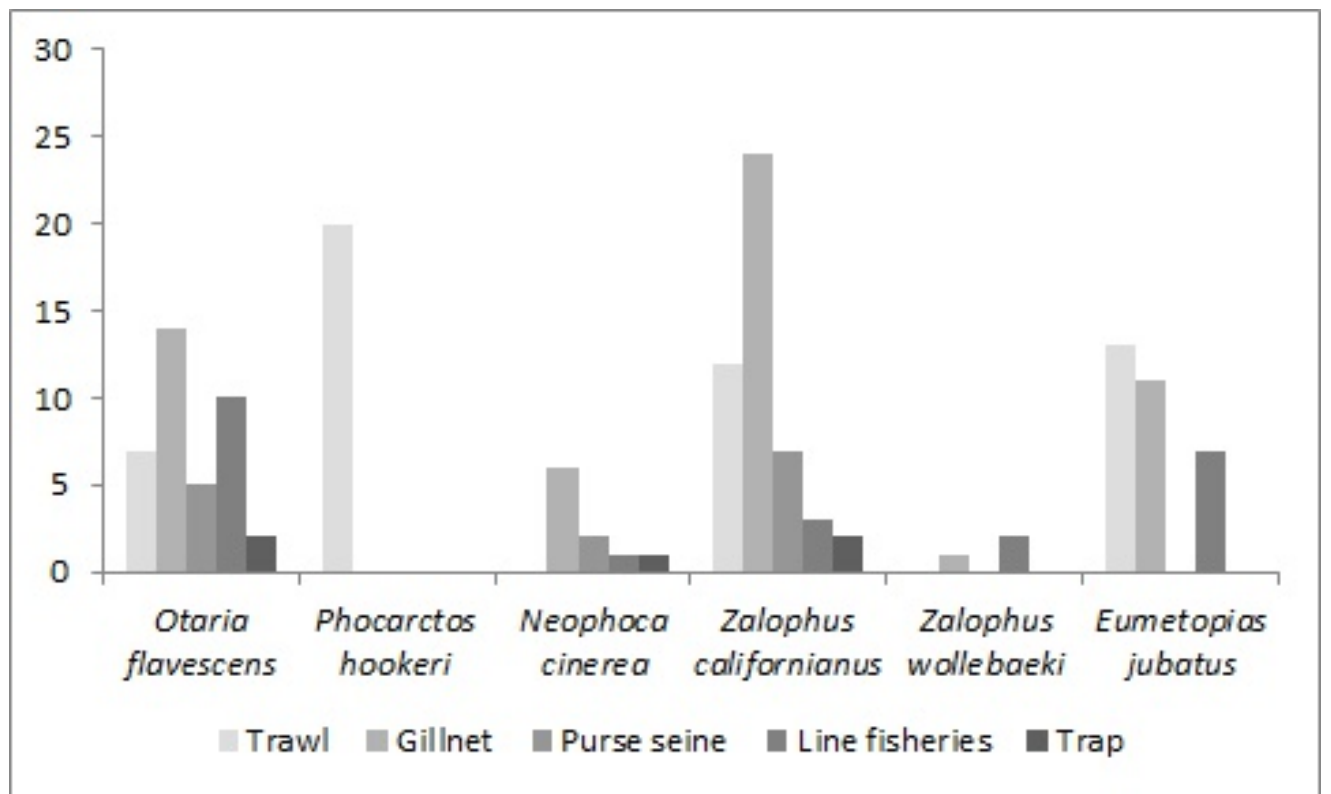

Figure 3. Number of studies on operational interactions with commercial fisheries by species of sea lions and fisheries. 


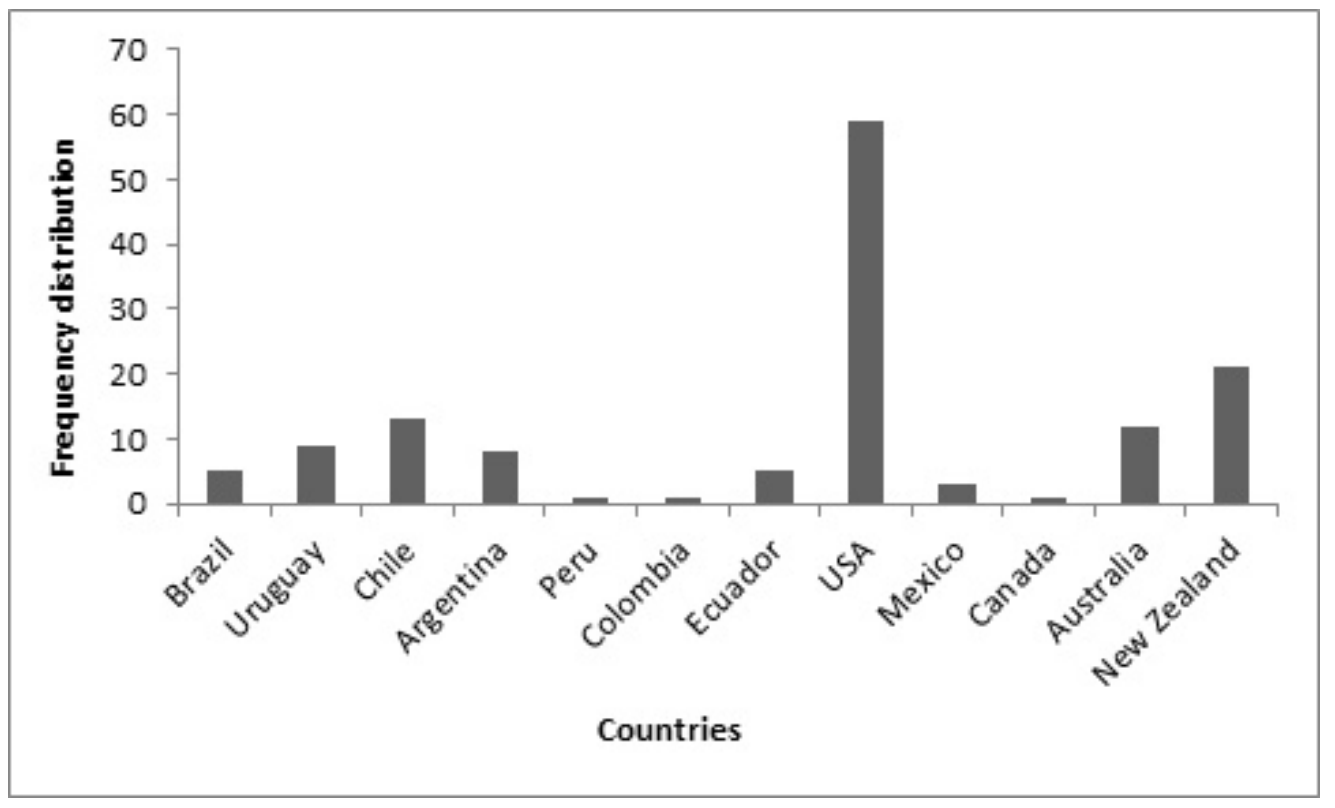

Figure 4. Number of studies on operational interactions with commercial fisheries and species of sea lions by country.

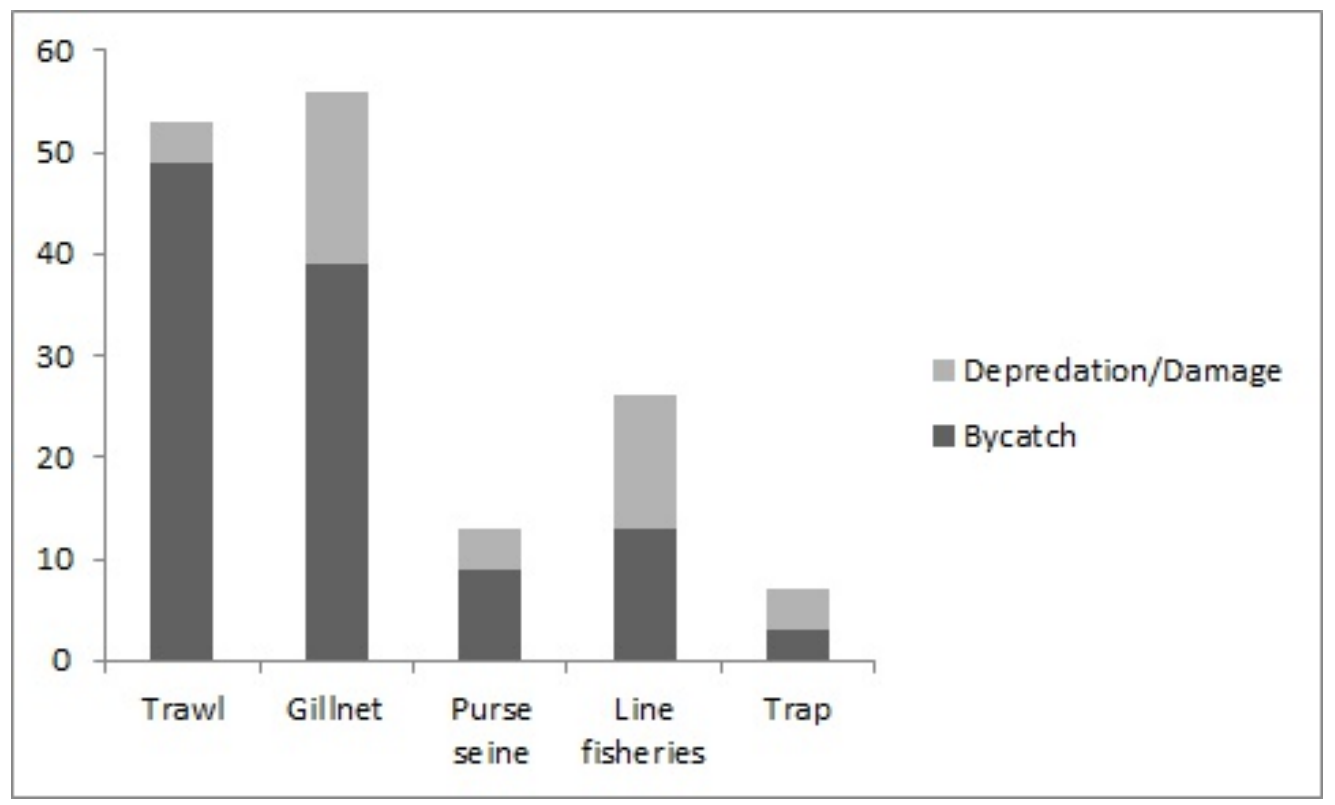

Figure 5. Frequency of bycatch and depredation/damage of sea lions by fishery.

\section{Phocarctos hookeri}

From the 21 studies that depicted the interactions with $P$. hookeri, 20 described interactions with trawl and one study with unidentifiable gear (Table 3).

\section{Neophoca cinerea}

From the 12 studies that depicted the interactions with $N$. cinerea, six described interactions with gillnets, two with purse seines, one with line fisheries, one with trap fishery and six with unidentifiable gear (Table 4). 


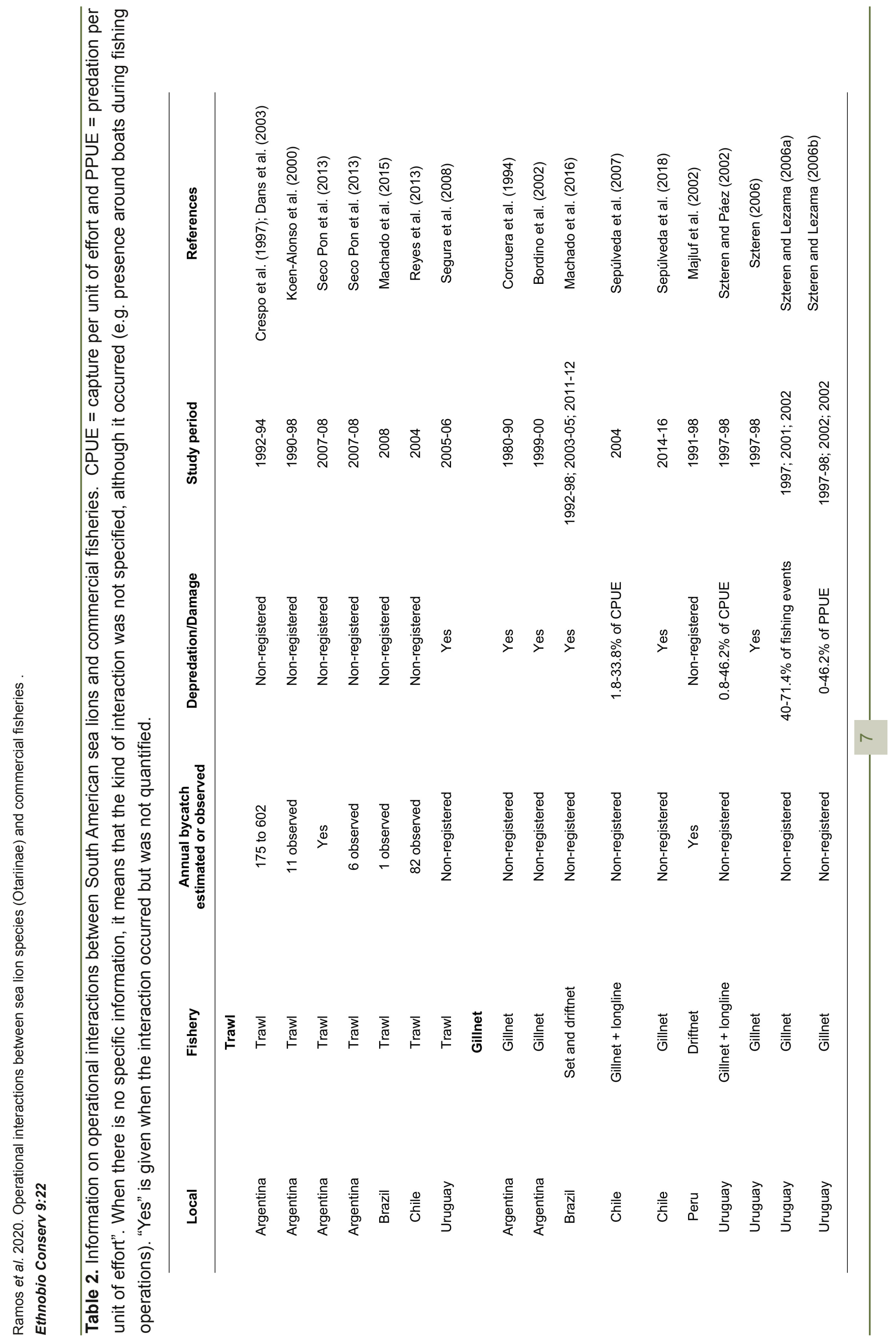




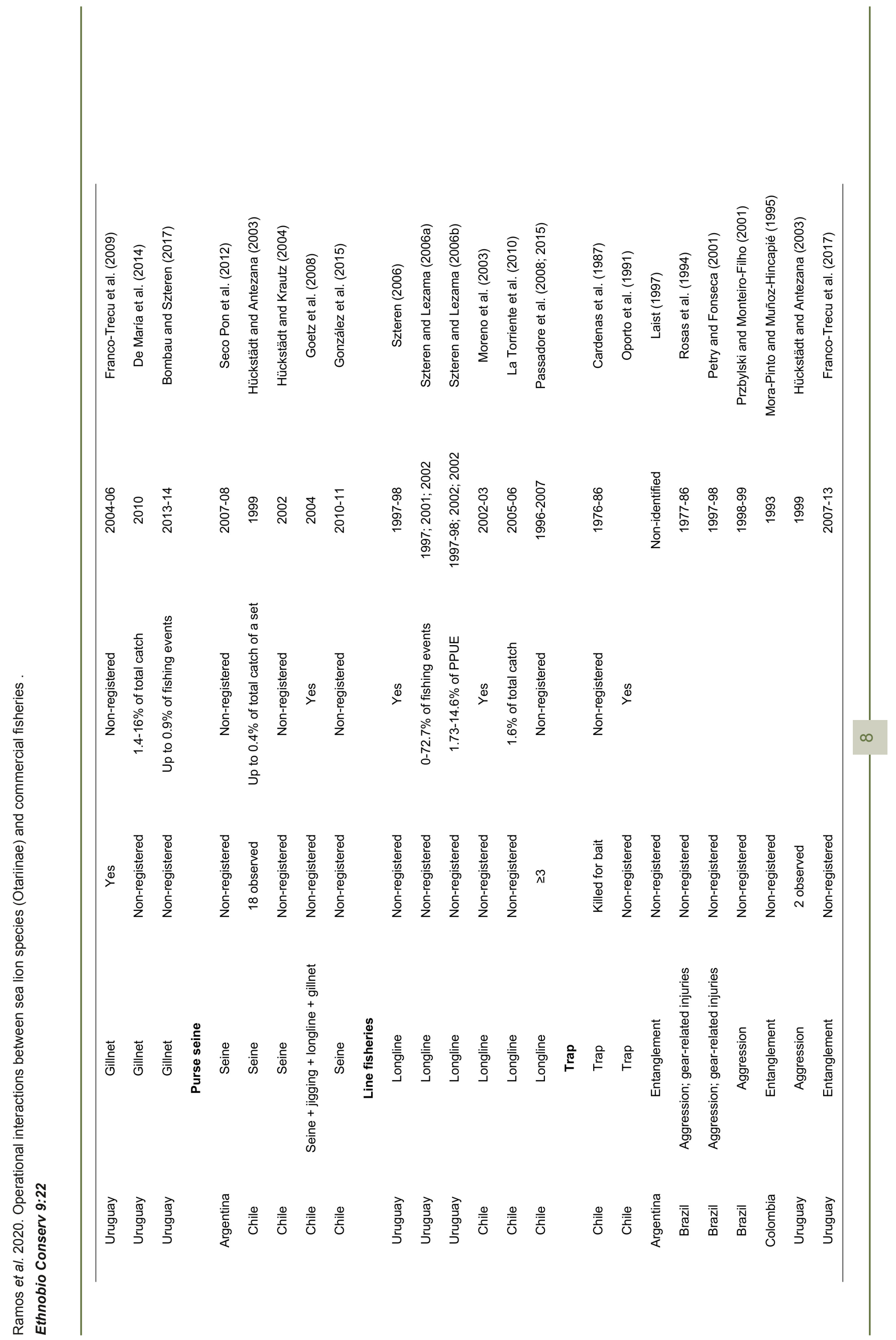


Table 3. Information on operational interactions between New Zealand sea lions and industrial trawl fisheries. In "Annual bycatch", average annual bycatch for the whole period is given in brackets.

\begin{tabular}{|c|c|c|c|c|}
\hline Local & Fishery & $\begin{array}{l}\text { Annual bycatch } \\
\text { estimated or observed }\end{array}$ & Study period & References \\
\hline & Trawl & & & \\
\hline New Zealand & Trawl & 17 to 141 & $1987-96$ & Baird (1996); Maunder et al. (2000) \\
\hline New Zealand & Trawl & 63 & 1998 & Baird (1999) \\
\hline New Zealand & Trawl & 71 & 2000 & Doonan (2000) \\
\hline New Zealand & Trawl & 12 & 1999 & Baird (2001) \\
\hline New Zealand & Trawl & 66 & 2001 & Doonan (2001) \\
\hline New Zealand & Trawl & 6 & 2001 & Doonan (2001) \\
\hline New Zealand & Trawl & 34 to 173 & $1991-96$ & Manly et al. (2002) \\
\hline New Zealand & Trawl & 14 to 141 & 1988-2002 & Breen et al. (2003) \\
\hline New Zealand & Trawl & 70 & 2000 & Baird (2004) \\
\hline New Zealand & Trawl & 40 & 2003 & Baird (2005b) \\
\hline New Zealand & Trawl & 74 & 2001-02 & Baird (2005a); Baird and Doonan (2005) \\
\hline New Zealand & Trawl & 185.2 & 2004 & Smith and Baird (2007) \\
\hline New Zealand & Trawl & 2 observed & 2003 & Smith and Baird (2007) \\
\hline New Zealand & Trawl & 1 observed & 2004 & Smith and Baird (2007) \\
\hline New Zealand & Trawl & 1 observed & 2004 & Smith and Baird (2007) \\
\hline New Zealand & Trawl & 14 to 123 & $1992-2007$ & Chilvers (2008) \\
\hline New Zealand & Trawl & 15 to 141 & $1995-2007$ & Thompson and Abraham (2009) \\
\hline New Zealand & Trawl & 1 to 14 & $2002-07$ & Thompson and Abraham (2009) \\
\hline New Zealand & Trawl & 12 & 2004-07 & Thompson and Abraham (2009) \\
\hline New Zealand & Trawl & 5 to 10 & 2004-07 & Thompson and Abraham (2009) \\
\hline New Zealand & Trawl & 14 to $123(73.3)$ & & Robertson and Chilvers (2011) \\
\hline New Zealand & Trawl & 14.4 to 163 & $1995-2006$ & Smith and Baird (2011) \\
\hline New Zealand & Trawl & 81 & $2009-11$ & Thompson et al. (2013) \\
\hline New Zealand & Trawl & 1 to 24 & $2007-11$ & Hamilton and Baker (2014) \\
\hline New Zealand & Trawl & 1 to 4 & $2006-11$ & Hamilton and Baker (2014) \\
\hline New Zealand & Trawl & 4 to 15 & $2006-11$ & Hamilton and Baker (2014) \\
\hline New Zealand & Trawl & 5 to 66 & $2006-11$ & Hamilton and Baker (2014) \\
\hline New Zealand & Trawl & 25 to 46 & $2006-11$ & Hamilton and Baker (2014) \\
\hline New Zealand & Trawl & 388 observed & $1991-2013$ & Thompson et al. (2015) \\
\hline Local & $\begin{array}{l}\text { Fishing } \\
\text { gear/debris }\end{array}$ & Number of individuals & Study period & References \\
\hline New Zealand & Entanglement & Non-registered & Non-identified & Laist (1997) \\
\hline
\end{tabular}


Table 4. Information on operational interactions between Australian sea lions and commercial fisheries. "Yes" is given when the interaction occurred but was not quantified.

\begin{tabular}{|c|c|c|c|c|c|}
\hline Local & Fishery & $\begin{array}{c}\text { Annual bycatch } \\
\text { estimated or observed }\end{array}$ & Depredation/Damage & Study period & References \\
\hline & Gillnet & & & & \\
\hline Australia & Gillnet & 1 observed & Non-registered & 1994-99 & McAuley and Simpfendorfer (2003) \\
\hline Australia & Gillnet & Yes & Non-registered & $1987-95$ & Shaughnessy et al. (2003) \\
\hline Australia & Gillnet & Yes & Yes & & NSSG and Stewardson (2007) \\
\hline Australia & Gillnet & 318 to 395 & Non-registered & 2006-09 & Goldsworthy et al. (2010) \\
\hline Australia & Gillnet & 9.5 to 22.5 & Non-registered & 2006-07 & Hamer et al. (2011) \\
\hline \multirow[t]{2}{*}{ Australia } & Gillnet & 193 to 227 & Non-registered & 2006-07 & Hamer et al. (2013) \\
\hline & Purse seine & & & & \\
\hline Australia & Purse seine & Yes & Non-registered & Non-identified & Shaughnessy et al. (2003) \\
\hline \multirow[t]{2}{*}{ Australia } & Purse seine & Non-registered & Yes & Non-identified & NSSG and Stewardson (2007) \\
\hline & Line fisheries & & & & \\
\hline \multirow[t]{2}{*}{ Australia } & Handline & Yes & Non-registered & Non-identified & NSSG and Stewardson (2007) \\
\hline & Trap & & & & \\
\hline Australia & Trap & 0 to 12 & Yes & 1999-2004 & Campbell et al. (2008) \\
\hline Local & Fishing gear/debris & Number of individuals & & Study period & References \\
\hline Australia & Entanglement & Non-registered & & $1987-92$ & Gales et al. (1994) \\
\hline Australia & Entanglement & 14 observed & & 1986-92 & Jones (1995) \\
\hline Australia & Entanglement & Non-registered & & $1980-96$ & Mawson and Coughran (1999) \\
\hline Australia & Entanglement & Non-registered & & 1988-2002 & Page et al. (2004) \\
\hline Australia & Entanglement & Non-registered & & Non-identified & NSSG and Stewardson (2007) \\
\hline Australia & Entanglement & 1 observed & & Non-identified & Byard and Machado (2018) \\
\hline
\end{tabular}

\section{Zalophus californianus}

From the 43 studies that depicted the interactions with $Z$. californianus, 23 described interactions with gillnets, 12 with trawls, seven with purse seines, three with line fisheries, two with trap fishery and 18 with unidentifiable gear (Table 5). All the studies with $Z$. californianus were carried out in the United States, except three that were conducted in Mexico. 


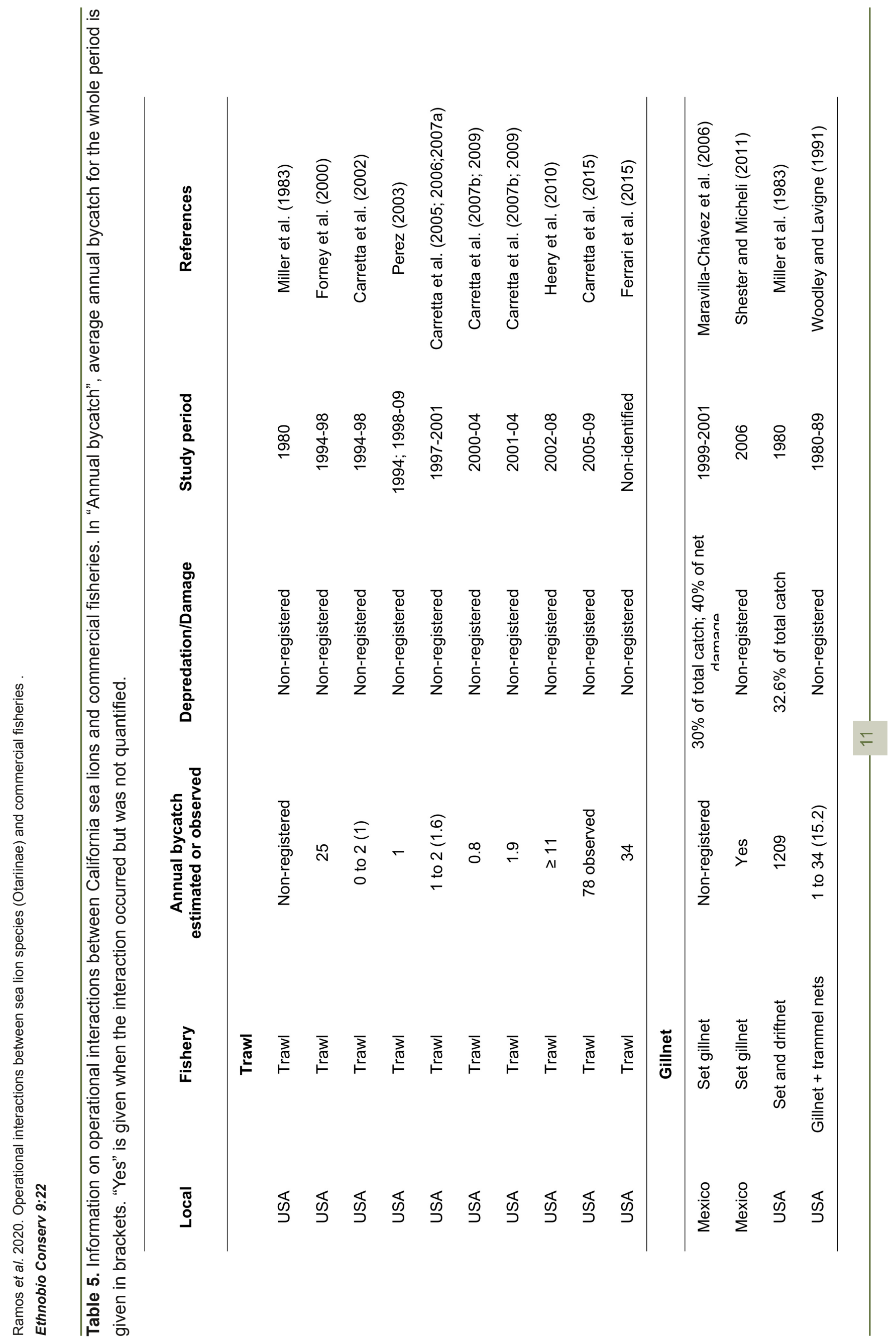




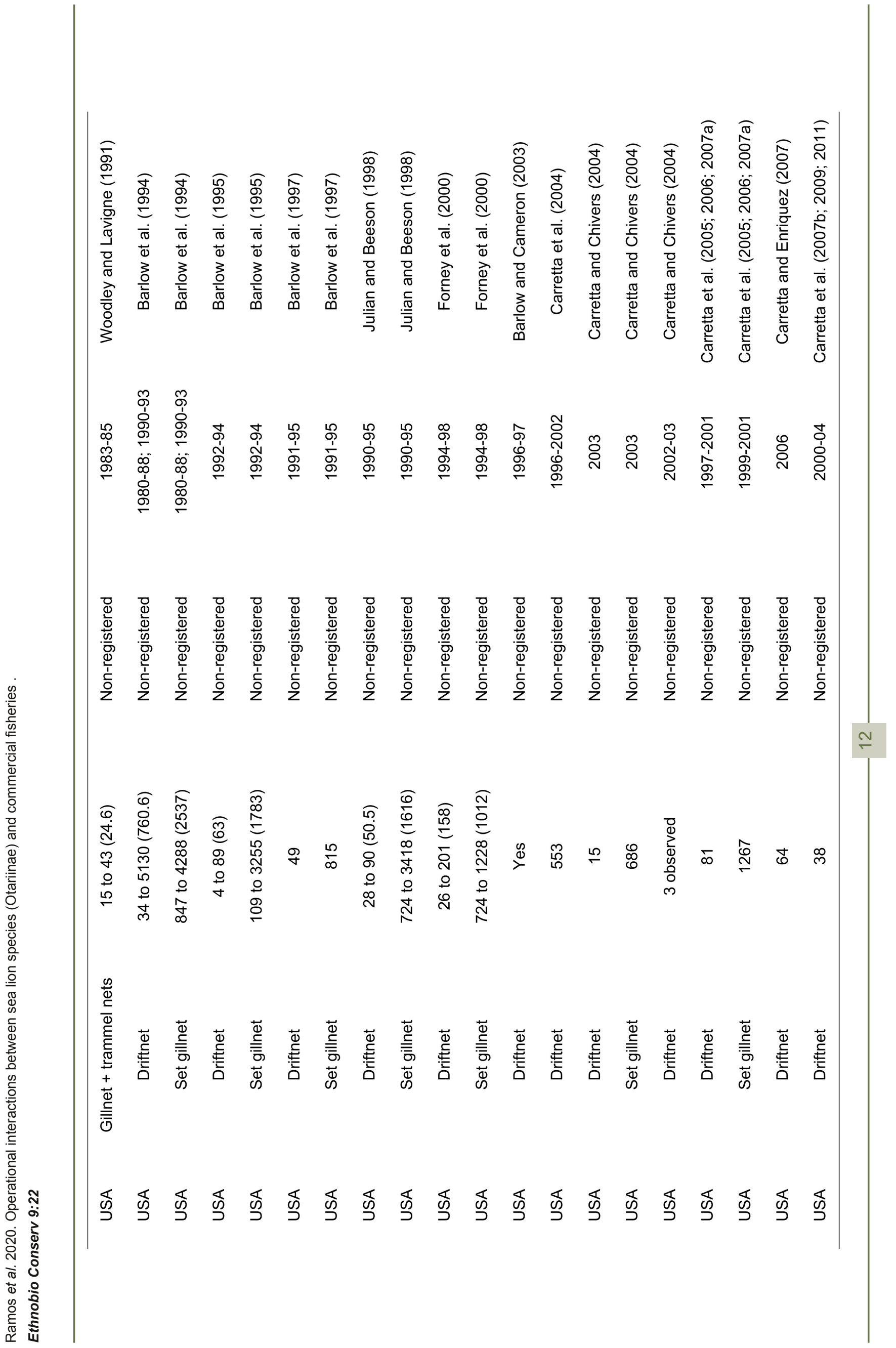




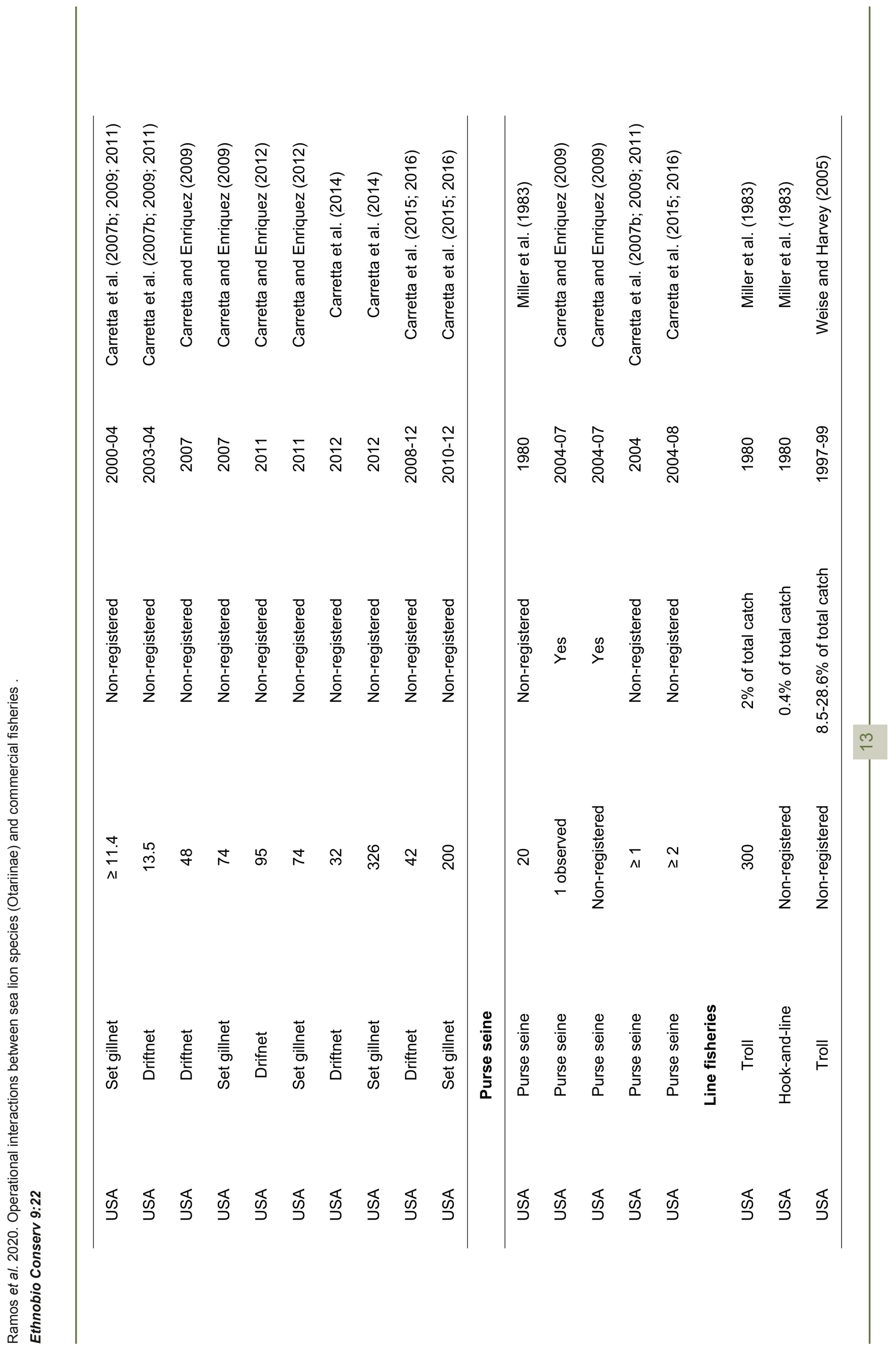




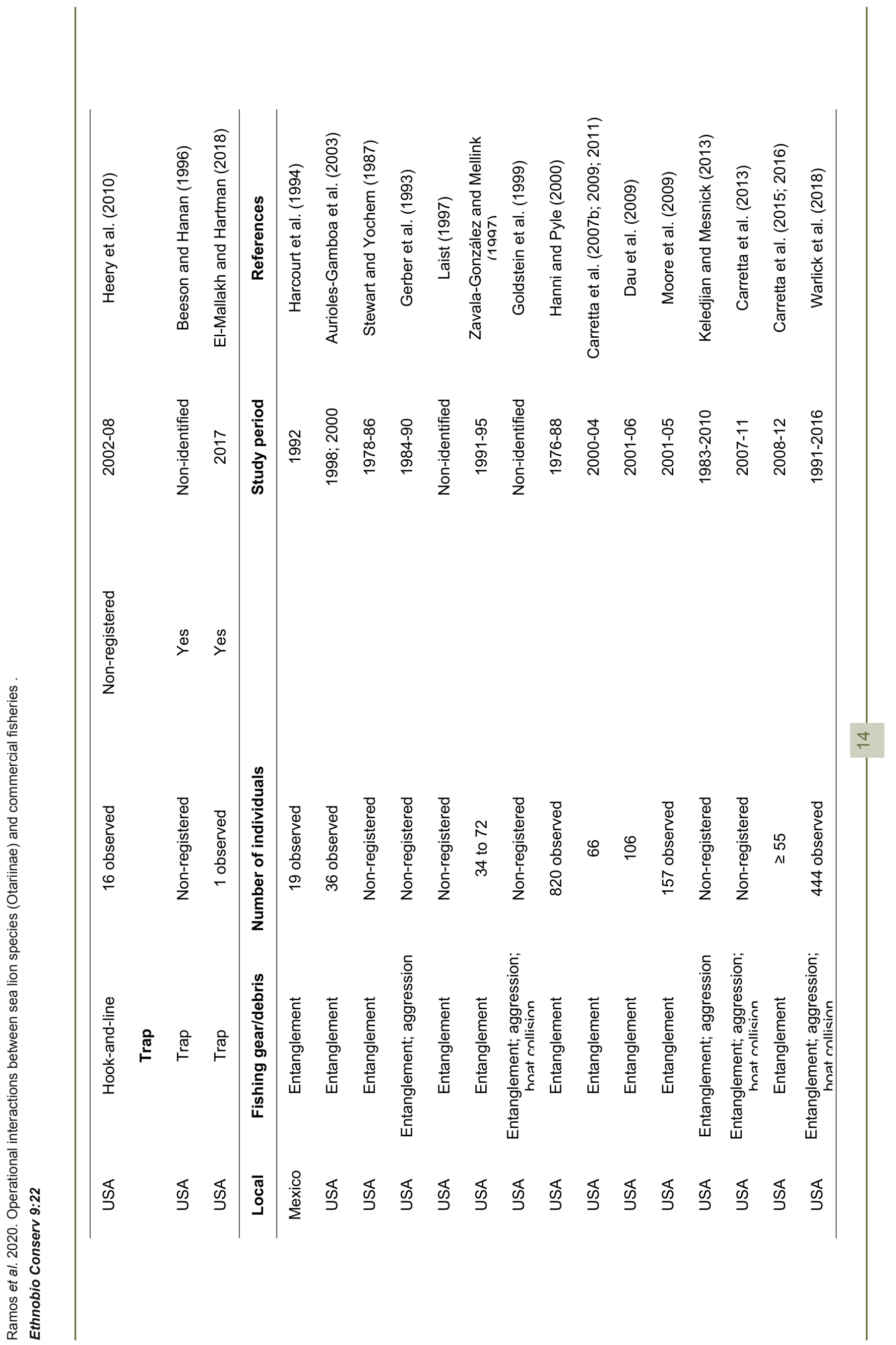




\section{Zalophus wollebaeki}

From the five studies that depicted the interactions with Z. wollebaeki, two described interactions with line fisheries, one with gillnet and three with unidentifiable gear (Table 6).

\section{Eumetopias jubatus}

From the 27 studies that depicted interactions with E. jubatus, 13 described interactions with trawls, 11 with gillnets, seven with line fisheries and nine with unidentifiable gear (Table 7).

Table 6. Information on operational interactions between Galapagos sea lions and commercial fisheries. "Yes" is given when the interaction occurred but was not quantified.

\begin{tabular}{|c|c|c|c|c|c|}
\hline Local & Fishery & $\begin{array}{l}\text { Annual bycatch } \\
\text { estimated or } \\
\text { observed }\end{array}$ & $\begin{array}{l}\text { Depredation/ } \\
\text { Damage }\end{array}$ & Study period & References \\
\hline \multirow{3}{*}{ Ecuador } & Gillnet & & & & \\
\hline & & Non-registered & Yes & 2012 & $\begin{array}{l}\text { Páez-Rosas and Guevara } \\
\text { (2017) }\end{array}$ \\
\hline & Line fisheries & & & & \\
\hline Ecuador & Longline & Non-registered & Yes & 2012 & $\begin{array}{l}\text { Páez-Rosas and Guevara } \\
\qquad(2017)\end{array}$ \\
\hline Ecuador & Handline & 2 observed & Non-registered & 2012 & Zimmerhackel et al. (2015) \\
\hline Local & $\begin{array}{l}\text { Fishing } \\
\text { gear/debris }\end{array}$ & $\begin{array}{l}\text { Number of } \\
\text { individuals }\end{array}$ & & Study period & References \\
\hline Ecuador & Entanglement & Non-registered & & Non-identified & Laist (1997) \\
\hline Ecuador & Entanglement & 251 observed & & $1995-2003$ & Alava and Salazar (2006) \\
\hline Ecuador & $\begin{array}{l}\text { Entanglement; } \\
\text { aggression; } \\
\text { boat collision; } \\
\text { harassment }\end{array}$ & Non-registered & & 2008-12 & Denkinger et al. (2015) \\
\hline
\end{tabular}

\section{DISCUSSION}

Z. californianus and $O$. flavescens are the species with the highest number of publications about operational interactions (Figure 2), although both are classified as "least concern". Regarding O. flavescens, this might be explained by the wide distribution of the species, covering several countries. Figure 4 shows that developed countries have more studies published, which is expected as they have more financial support for research.

Trawl and gillnet presented the highest frequency and number of incidental captures of sea lions (Figure 5), a phenomenon that is generally observed in other studies about marine mammals. According to Read et al. (2006), in the early 1990s, from 536,158 to 822,706 cetaceans and pinnipeds died annually because of incidental captures worldwide, and gillnets were mostly responsible for the interactions with cetaceans (84\%) and pinnipeds (98\%). Reeves et al. (2013) found that at least $75 \%$ of species of odontocetes, $64 \%$ of mysticetes and $66 \%$ of pinnipeds were caught by gillnets between 1990 and 2011, 


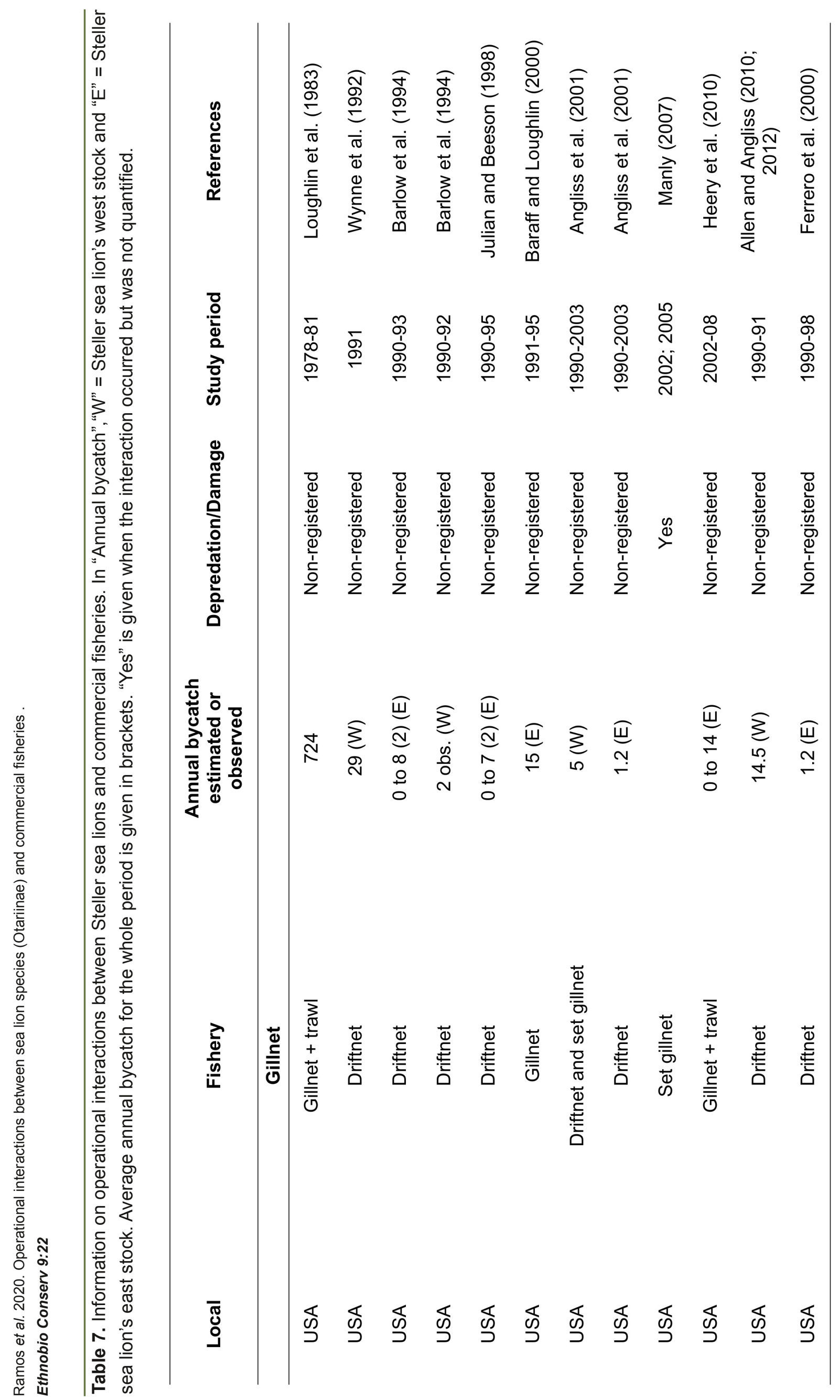




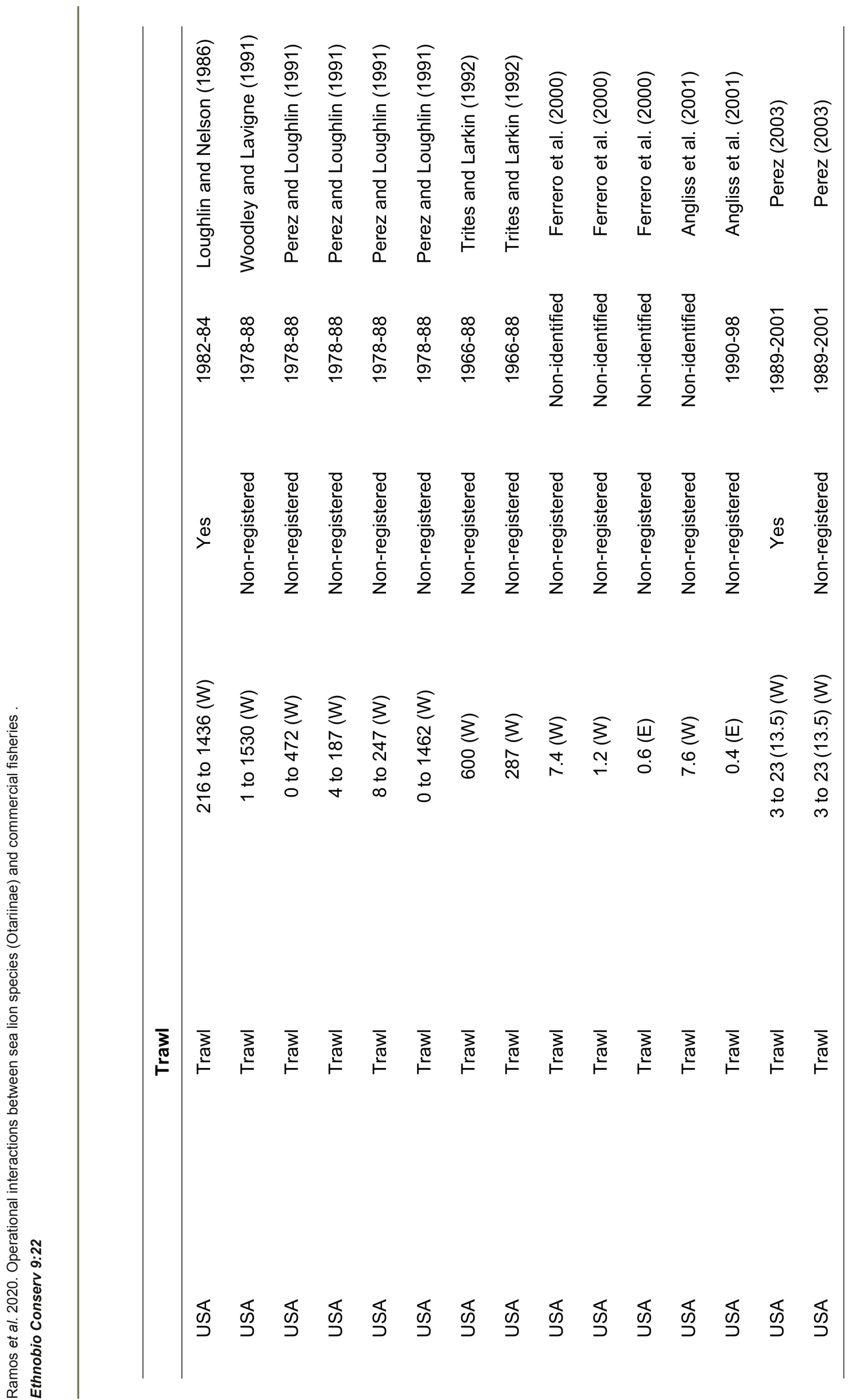




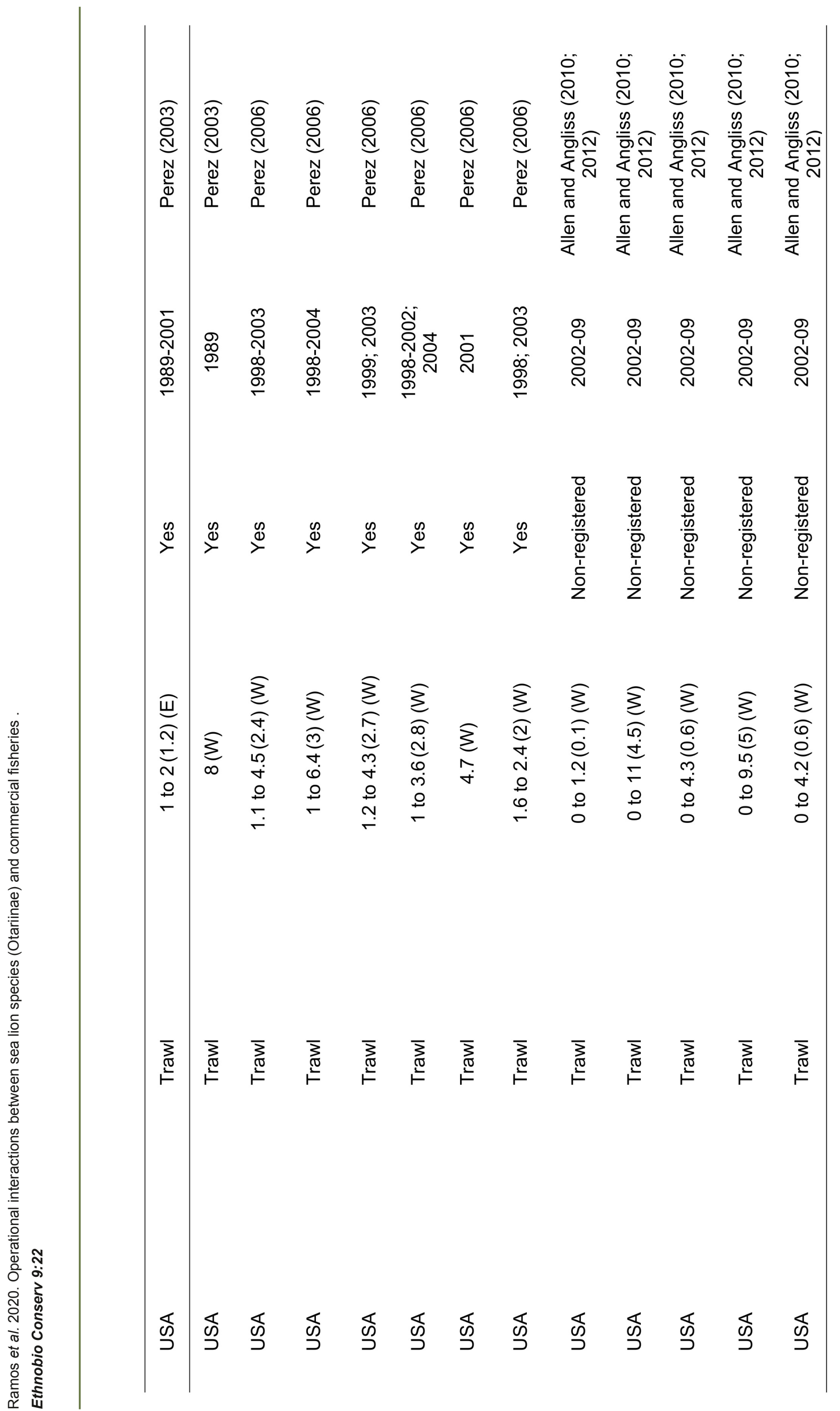




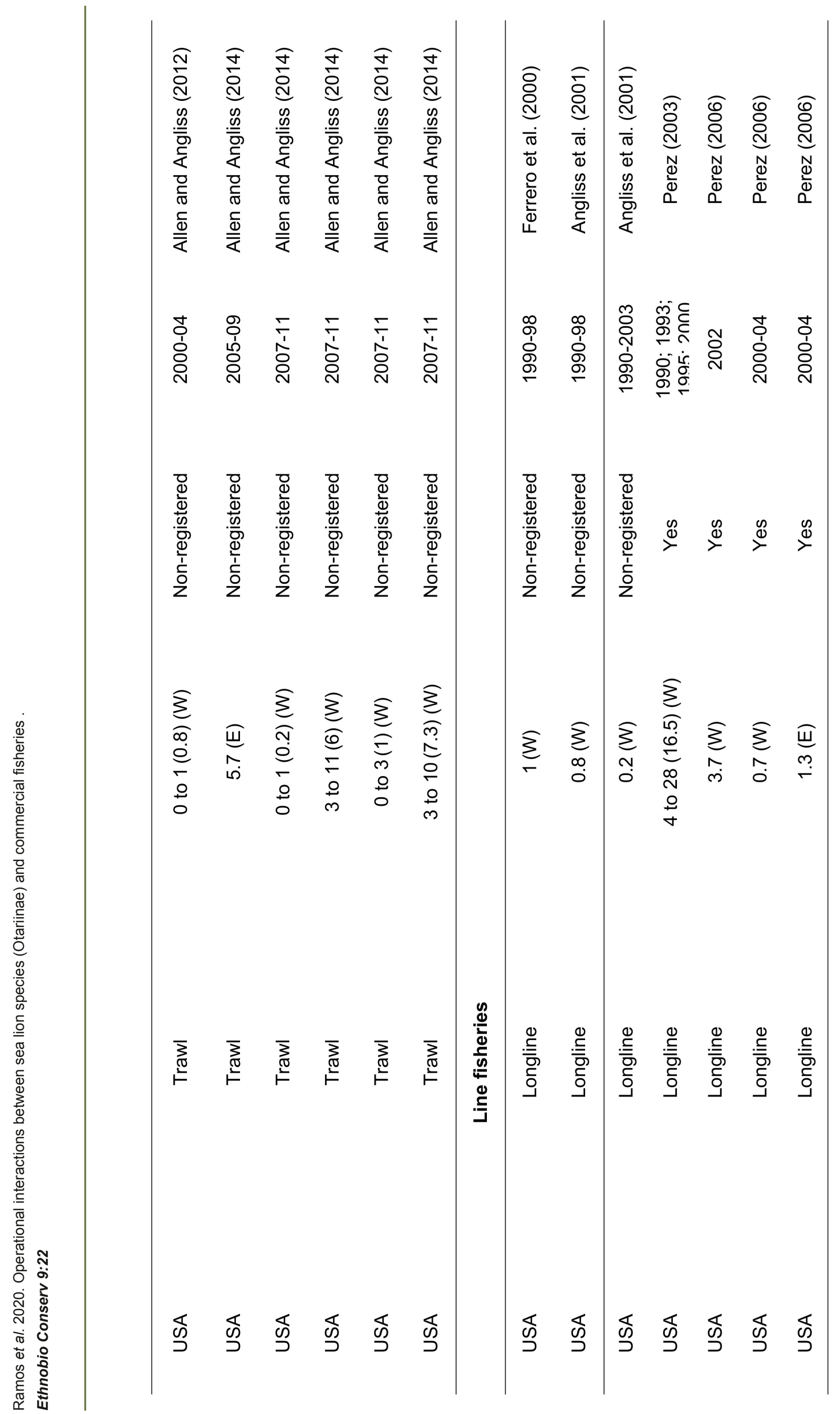




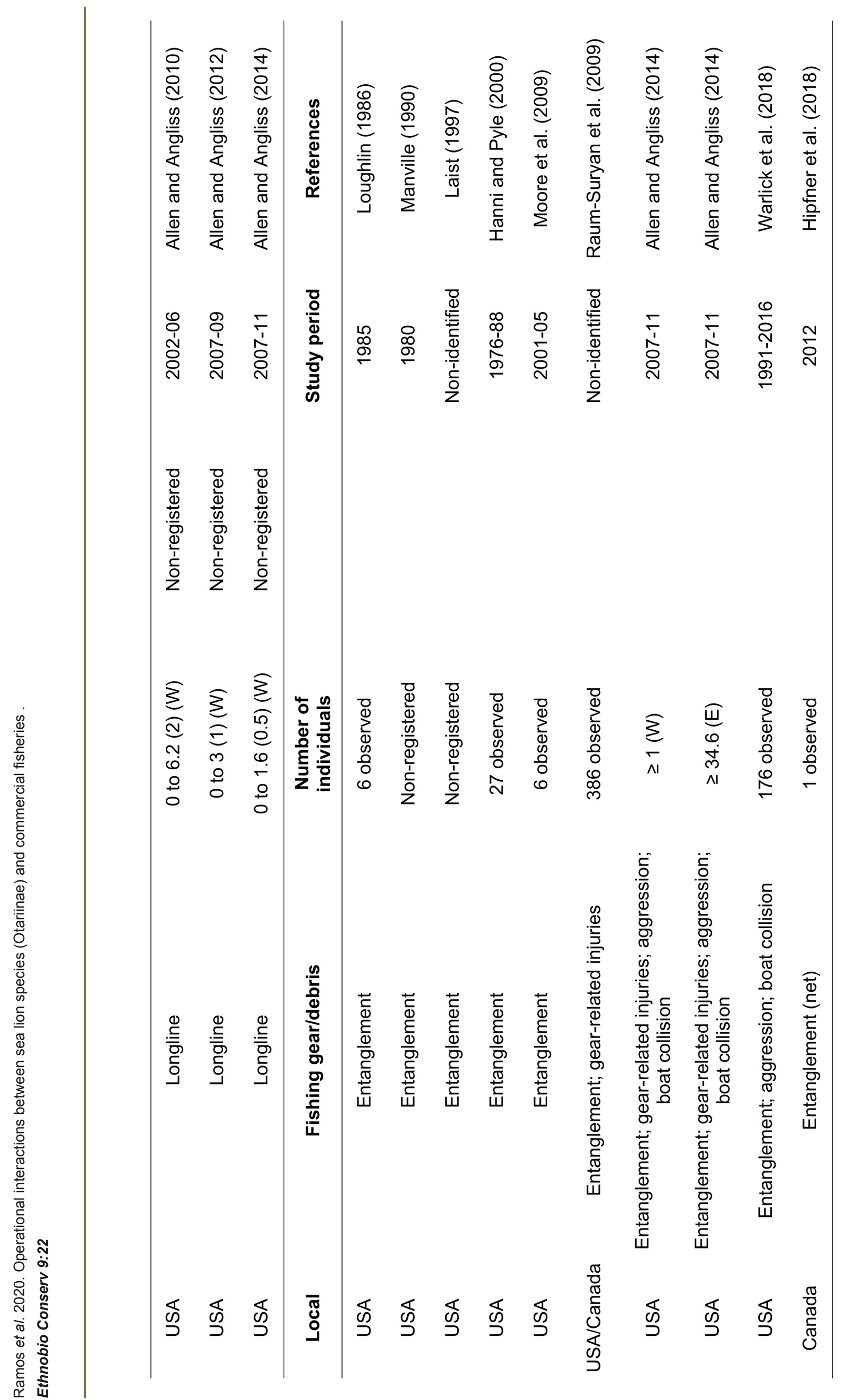


in addition to four species of sirenians and two species of sea otters.

Although aggressions seemed most common for $O$. flavescens, Z. californianus and $E$. jubatus, other species could be equally affected by this type of interaction. The higher number of aggressions reported could simply be a result of the greater number of publications for the three species.

\section{Otaria flavescens}

Considering all the species analysed, research conducted with sea lions in South America provided more data on the magnitude of the economic loss caused by sea lions (predation and gear damage). The commercial losses caused by the predation of sea lions in artisanal fishery in Uruguay (Szteren and Páez 2002) and Chile (Sepúlveda et al. 2007) demonstrated a wide variation and cannot be attributed exclusively to gillnet fishing since these studies evaluated line fishery together with gillnet fishing. In general, these losses were considered low (De María et al. 2014; Szteren and Páez 2002).

In southern Brazil, the bycatch of $O$. flavescens in gillnets is apparently an uncommon phenomenon, despite the occurrence of interactions and conflicts, especially in the winter (Machado et al. 2016). In Chile, Reyes et al. (2013) demonstrated that these interactions with trawl boats are alarming since they can remove many individuals from the population in a short period (82 individuals captured in 10 days) and, although only $14.6 \%$ of the sea lions were captured dead, those who survived were released with serious injuries and a high probability of subsequent death (Reyes et al., 2013). Machado et al. (2015) describe that the interactions between $O$. flavescens and the fisheries in southern Brazil may be contributing to the decline of the population in Uruguay, which showed an annual population reduction of $1.6 \%$ to $2.0 \%$ (Crespo et al. 2012; Páez 2005). The authors are also concerned about the lack of monitoring of the trawl fleet in southern Brazil, which prevents evaluations of the impact of this activity on the population.

Gillnet fishing in southern Brazil had the lowest interaction frequency for $O$. flavescens (interactions in $24 \%$ of the sets) but showed a high level of depredation, which occurred in $85.3 \%$ of the sets with interactions (Machado et al. 2016). This level of predation was greater than in Uruguay (predation on $51 \%$ of gillnet and longline sets; Szteren and Páez 2002), considering that unlike Brazil, Uruguay hosts breeding colonies where sea lions are much more abundant. Sepúlveda et al. (2007) reported interactions with $O$. flavescens in up to $71.4 \%$ of the fishing days and $14.5 \%$ of the gillnet, longline and handline fishing trips in Chile. Additionally, De María et al. (2014) recorded the occurrence of interactions between $40.5 \%$ and $63.4 \%$ of the gillnet sets in Uruguay.

It is possible that the fisheries monitored by Machado et al. (2016) suffered fewer loss impacts than the fisheries in Uruguay (De María et al. 2014; Szteren and Páez 2002) and Chile (Sepúlveda et al. 2007). However, Machado et al. (2016) monitored mediumscale vessels with greater autonomy of fishing than the ones observed by De María et al. (2014), Sepúlveda et al. (2007) and Szteren and Páez (2002), all of whom monitored artisanal fisheries with low fishing autonomy. In Peru, only one study described the interactions between fishing and pinnipeds (Majluf et al. 2008).

Regarding line fishing, only Passadore et al. $(2008,2015)$ recorded incidental captures 
in Chile. Nevertheless, La Torriente et al. (2010) reported that sea lions interacted with longlines in $58.3 \%$ of the fishing sets, with predation in $52 \%$ of these sets.

The species $O$. flavescens had the highest number of individuals that simultaneously interacted with fisheries. In general, about 10 individuals of 0 . flavescens were present in the interactions (De María et al. 2014; Machado et al. 2016; Sepúlveda et al. 2007; Szteren and Páez 2002), except in the case of purse seine fishing in Chile, with the presence of up to 290 sea lions (González et al. 2015; Hückstädt and Antezana 2003). Studies conducted in Brazil, Argentina, Uruguay and Colombia contained records of stranded dead animals with aggression marks, such as shots and strikes, and entangled in fishing gear (Table 2). There are old records of an intentional capture of the species as bait for trap fishing in Chile (Cardenas et al. 1987; Oporto et al. 1991). Adult females and subadult males of $O$. flavescens were the most commonly affected groups in interactions of Uruguayan fisheries (Szteren and Páez 2002).

\section{Phocarctos hookeri}

Females in reproductive age were the most common specimens accidentally captured in the squid trawl fishery in New Zealand (from $57 \%$ to $87.5 \%$ of the bycatch of $P$. hookeri (Baird and Doonan 2005; Smith and Baird 2007; 2011). Moreover, this fishery was responsible for high mortality rates of sea lions (Baird and Doonan 2005; Doonan 2001; Manly et al. 2002; Thompson and Abraham 2009; Thompson et al. 2015). According to Chilvers (2008) and the literature (Table 3 ), the bycatch of sea lions in this fishery did not significantly decrease after the introduction of sea lion excluder devices (SLED), and many that come out alive suffer severe internal injuries, compromising the post-release survival rate (Wilkinson et al. 2003). SLEDs are devices through which pinnipeds can be ejected and escape from trawl nets (Doonan 2001). Furthermore, the use of SLEDs prevented the direct count of injured and dead animals in the nets. In addition, the proportion of females captured has increased by up to $82 \%$ since 2004 (Chilvers 2008). For P. hookeri, quotas have been established every year for the squid trawl fishery in New Zealand since 1992. In this country, most of the fleet has onboard observers that halt fishing when the limits are reached (Chilvers 2008).

\section{Neophoca cinerea}

Purse seine fisheries did not quantify incidental captures and gillnet fisheries seemed to be the most dangerous in terms of number of sea lions captured (Figure 3; Table 4). This Australian endemic species is particularly vulnerable to extinction as its population breeds in the same rookeries where it was born (Gales et al. 1994). In Australia, few specimens of $\mathrm{N}$. cinerea die per year due to trap fishing, but mortality reaches more than $80 \%$ for captured sea lions (Campbell et al. 2008). Marine Protected Areas (MPAs) do not always manage to protect a species from fishing impacts. In Australia and New Zealand, fishing exclusion zones in MPAs do not cover the entire foraging area of sea lions (Chilvers 2009; Hamer et al. 2011). However, when MPAs are well planned, they can significantly improve the survival probability of endangered species (Gormley et al. 2012). In Australia, the current levels of $\mathrm{N}$. cinerea bycatch (Table 4) are apparently low but may still cause a population decline (Hamer et al. 2011). Entanglements were very common for this species. 


\section{Zalophus californianus}

From the 43 studies that depicted interactions with $Z$. californianus, 23 described interactions with gillnets, 12 with trawls, seven with purse seines, three with line fisheries, two with trap fishery and 18 with unidentifiable gear (Table 5). All the studies with Z. californianus were carried out in the United States, except three that were conducted in Mexico.

Gillnet fisheries showed the highest incidental captures of California sea lions, especially in the case of set nets. Barlow and Cameron (2003) evaluated the effectiveness of acoustic deterrents (pingers) in drift gillnets in California, which may register $100 \%$ mortality among captured individuals of $Z$. californianus. Pingers are active sound emitters set on nets which alert individuals of the presence of the fishing gear aiming to avoid their capture (Dawson et al. 2013). The authors found that the rate of bycatch was lower in nets with pingers. However, even with the mandatory use of pingers in drift gillnets since 1997, the annual bycatch estimates for the period 1996-2007 were higher than in previous years (Carretta et al. 2004). In addition, after the initial reduction in the number of animals captured as bycatch, these animals can become habituated to the sound emitted by the pingers, leading to a reverse effect, especially in areas with a large number of boats (Barlow and Cameron 2003). Entanglements were very common for this species. Maravilla-Chávez et al. (2006) reported a reduction of depredation and gear damage just by reducing daily fishing trips and watching over the gillnets in the water.

\section{Zalophus wollebaeki}

Fisheries in Ecuador reported only two sea lions incidentally captured (handline) and the occurrence of depredation and damage in longline and gillnet fisheries, without details. Moreover, 251 individuals, mostly juveniles and adults, were found entangled by non-specified fishing gear and were affected by other kinds of operational interaction, like boat collision, aggression and harassment. Only gillnet and line fisheries interactions were recorded.

\section{Eumetopias jubatus}

Until the end of the 1980s, fisheries showed the greatest numbers of Steller sea lions bycatch, although this tendency could not be found in other fisheries besides trawl. Since then, incidental captures seem to have decreased significantly.

Depredation occurred in all kinds of fisheries for $E$. jubatus, although without details. No information about group size or economic loss was recorded. Information on the interactions for the west stock was more abundant than for the east stock. Entanglements and aggressions were also common for this species. The species is divided into two different stocks according to their distribution: the east stock of 1440 latitude and the west stock of 1440 latitude (Phillips et al. 2009), the latter of which has suffered a population decline of more than $80 \%$ (Atkinson et al. 2008).

Although the focus of this study is the effects of operational interactions on different sea lion species, some of the studies presented information on the need to conduct comparative research for the species analysed here, and additionally seek to make their conservation more effective. For example, the current and future effects 
of capture on reproductive females were addressed, as exemplified for $P$. hookeri (Baird and Doonan 2005; Smith and Baird 2007 ; 2011), as well as the most negatively affected species.

Additionally, Chilvers (2008) called into question the real effectiveness of SLEDs, which can be tested in relation to speciesspecific variables (prey size, fishing schedule, target species, etc.) or in relation to the functioning of devices (speed, size, intensity, etc.).

Despite the high number of studies on the effectiveness of Marine Protected Areas (MPAs) (Brandão et al. 2017; Giglio et al. 2019), these studies chiefly focus on general data about threats and risks. For the effective protection of the species presented here, MPAs must incorporate specific biological variables, such as dependence on foraging and/or reproduction sites, and the direction and intensity of the routes of vessels that use the most harmful gear, already identified in this study as trawl and gillnet. Besides, no-take zones can be beneficial not only for marine megafauna but also for the fishing sector, as these zones favour the spillover effect that enhances the sustainability of fisheries by exporting fish to surrounding areas (Forcada et al. 2009).

\section{CONCLUSIONS}

The identified operational interactions were bycatch, the presence of animals around boats during fishing operations, depredation, gear damage, entanglement in lost/discarded fishing gear, boat collisions, aggressions (shooting and striking), gearrelated injuries, such as net marks and gear swallowing, and harassment. Trawl and gillnet fisheries captured more sea lions and more frequently than the other fisheries. Depredation and gear damage were more common for gillnet and line fisheries. Other interactions like entanglement and aggressions were also very common for all species.

Interactions in all fisheries should be equally assessed with the data of onboard observers and different strategies should be tested to avoid negative interactions and their consequences. These strategies can include bycatch limits (quotas), changes in fishing practices such as setting nets when pinnipeds are not active, reduced soaking time of gillnets and the avoidance of onboard discard in trawl operations, reduced fishing effort and the establishment of effective MPAs. The establishment of MPAs, especially in coastal waters, which is the area mainly inhabited by many species of pinnipeds, could significantly reduce the fishing effort and, therefore, reduce negative fishery-induced impacts on pinnipeds. MPAs, however, must not only protect rookeries and haul-out sites, but also foraging areas. Moreover, data on the magnitude of commercial losses caused by pinnipeds should be better investigated to show the real impact of this type of interaction on fisheries economy, which is commonly overestimated by fishermen. In addition, more efforts should be directed at identifying age and gender of the most affected pinnipeds. The data on bycatch and other variables should be standardized to enable comparisons of information between fisheries and sites. Finally, we suggest gathering data on the number of sea lions interacting with fisheries, so interaction hotspots can be identified for more efficient conflict management. 


\section{ACKNOWLEDGEMENTS}

The authors would like to thank the anonymous reviewers for their insightful comments on the paper; Coordenação de Aperfeiçoamento de Pessoal de Nível Supeior (CAPES), for providing a Ph.D. grant to K.L.R; and Conselho Nacional de Desenvolvimento Científico e Tecnológico (CNPq), for the productivity grant awarded to the last author.

\section{DATA AVAILABILITY}

The data used to support the findings of this study are available from the corresponding author upon reasonable request.

\section{CONFLICTS OF INTEREST}

The authors have no conflicts of interest to declare.

\section{CONTRIBUTION STATEMENT}

Conceived the presented idea: KLR.

Carried out the bibliographic review: KLR.

Carried out the data analysis: KLR, RM, AS.

Wrote the first draft of the manuscript: KLR.

Review and final write of the manuscript: KLR, RM, AS.

Supervision: AS.

\section{REFERENCES}

Alava JJ, Salazar S (2006) Status and conservation of otariids in Ecuador and the Galápagos Islands. In: Trites AW, DeMaster DP, Fritz LW, Gelatt TS, Rea LD, Wayne KM (eds) Sea Lions of the World. Alaska Sea Grant Program, Fairbanks, pp. 495-520.
Angliss RP, DeMaster DP, Lopez AL (2001) Alaska marine mammal stock assessments, 2001. U.S. Dep. Commer., NOAA Tech. Memo, NMFS-AFSC-124, 203 pp.

Allen BM, Angliss RP (2010) Alaska marine mammal stock assessments, 2009. U.S. Dep. Commer., NOAA Tech. Memo, NMFS-AFSC-206, $276 \mathrm{pp}$.

Allen BM, Angliss RP (2012) Alaska marine mammal stock assessments, 2011. U.S. Dep. Commer., NOAA Tech. Memo, NMFS-AFSC-234, $288 \mathrm{pp}$

Allen BM, Angliss RP (2014) Alaska marine mammal stock assessments, 2013. US Dep.Commer., NOAA Tech. Memo, NMFSAFSC-277, 294 pp.

Alverson DL, Freeberg MH, Pope JG, Murawski SA (1994) A global assessment of fisheries bycatch and discards. FAO Fisheries Technical Paper 339, 233 pp.

Atkinson S, DeMaster DP, Calkins DG (2008) Anthropogenic causes of the western Steller sea lion Eumetopias jubatus population decline and their threat to recovery. Mammal Review 38(1): 1-18.

Aurioles-Gamboa D, García-Rodríguez F, Ramírez-Rodríguez M, Hernández-Camacho C (2003) Interaction between the California sea lion and the artisanal fishery in La Paz Bay, Gulf of California, Mexico. Ciencias Marinas 29(3): 357-370.

Aurioles-Gamboa D, Hernández-Camacho C (2015) Zalophus californianus (In: IUCN Red List of Threatened Species 2015). IUCN. (https://dx.doi.org/10.2305/IUCN.UK.20154.RLTS.T41666A45230310.en). Accessed 21 January 2020.

Baird SJ (1996) Nonfish species and fisheries interactions working group report - May 1996. New Zealand Fisheries Assessment Working Group Report 96/1, 27 pp.

Baird SJ (1999). Estimation of nonfish bycatch in commercial fisheries in New Zealand waters, 1997-98. Unpublished report completed for Objective 1 of Ministry of Fisheries Project ENV9801, $57 \mathrm{pp}$.

Baird SJ (2001) Estimation of the incidental capture of seabird and marine mammal species in commercial fisheries in New Zealand waters, 1998-99. New Zealand Fisheries Assessment Report 14, 43 pp. 
Baird SJ (2004) Estimation of the incidental capture of seabird and marine mammal species in commercial fisheries in New Zealand waters, 1999-2000. New Zealand Fisheries Assessment Report 41, 56 pp.

Baird SJ, Doonan IJ (2005) Phocarctos hookeri (New Zealand sea lions): incidental captures in New Zealand commercial fisheries during 2000-01 and in-season estimates of captures during squid trawling in SQU 6T in 2002. New Zealand Fisheries Assessment Report 17, 18 pp.

Baird SJ (2005a) Incidental capture of Phocarctos hookeri (New Zealand sea lions) in New Zealand commercial fisheries, 200102. New Zealand Fisheries Assessment Report 8, $17 \mathrm{pp}$.

Baird SJ (2005b) Incidental capture of Phocarctos hookeri (New Zealand sea lions) in New Zealand commercial fisheries, 200203. New Zealand Fisheries Assessment Report 9, 13 pp.

Baraff LS, Loughlin TR (2000) Trends and potential interactions between pinnipeds and fisheries of New England and the U.S. west coast. Marine Fisheries Review 64(2): 1-39.

Barlow J, Cameron GA (2003) Field experiments show that acoustic pingers reduce marine mammal bycatch in the California drift gill net fishery. Marine Mammal Science 19(2): 265-283.

Barlow J, Baird RW, Heyning JE, Wynne K, Manville AM, Lowry LF, Hanan D, Sease J, Burkanov VN (1994) A review of cetacean and pinniped mortality in coastal fisheries along the west coast of the USA and Canada and the east coast of the Russian federation. Reports of the International Whaling Commission 15: 405-426.

Barlow J, Brownell RL, DeMaster DP, Forney KA, Lowry MS, Osmeck S, Ragen TJ, Reeves RR, Small RJ (1995) U.S. Pacific marine mammal stock assessments. NOAA-TM-NMFS-SWFSC219, $162 \mathrm{pp}$.

Barlow J, Forney KA, Hill PS, Brownell RL, Carretta JV, DeMaster DP, F. Julian F, Lowry MS, Ragen T, Reeves RR (1997) U.S. Pacific marine mammal stock assessments: 1996. U.S. Dep. Commer., NOAA-TM-NMFS-SWFSC-248, 223 pp.
Beeson MJ, Hanan DA (1996) An evaluation of pinniped-fishery interactions in California. Marine Resources Division, California Department of Fish and Game, Report to the Pacific States Marine Fisheries Commission, 47 pp.

Beverton RJH (1985) Analysis of marine mammal-fisheries interactions. In: Beddington JR, Beverton RJH, Lavigne DM (eds) Marine mammals and fisheries. George Allen and Unwin, London, pp. 4-33.

Bombau A, Szteren D (2017) Seasonal variability of South American fur seals (Arctocephalus australis) and sea lions (Otaria flavescens) in two haulouts and interactions with small-scale fisheries off the coast of Montevideo, Uruguay. Aquatic Mammals 43(5): 479-491.

Bordino P, Kraus S, Albareda D, Fazio A, Palmerio A, Mendez M, Botta S (2002) Reducing incidental mortality of franciscana dolphin Pontoporia blainvillei with acoustic warning devices attached to fishing nets. Marine Mammal Science 18(4): 833-842.

Brandão CS, Malta A, Schiavetti A (2017) Temporal assessment of the management effectiveness of reef environments: the role of marine protected areas in Brazil. Ocean \& Coastal Management 142: 111-121.

Breen PA, Hilborn R, Maunder MN, Kim SW (2003) Effects of alternative control rules on the conflict between a fishery and a threatened sea lion (Phocarctos hookeri). Canadian Journal of Fisheries and Aquatic Sciences 60: 527-541.

Byard RW, Machado A (2018) Characteristic "neck collar" injuries in Australian sea lions (Neophoca cinerea) caused by marine debris. Forensic Science, Medicine and Pathology 15(4): 631-634.

Campbell R, Holley D, Christianopoulos D, Caputi N, Gales N (2008) Mitigation of incidental mortality of Australian sea lions in the west coast rock lobster fishery. Endangered Species Research 5: 345-358.

Cárdenas-Alayza S, Crespo E, Oliveira L (2016) Otaria byronia (In: IUCN Red List of Threatened Species 2016). IUCN. (http://dx.doi.org/10.2305/ IUCN.UK.20161.RLTS.T41665A61948292.en). Accessed 1 June 2019. 
Cardenas JC, Gibbons J, Oporto J, Stutzin M (1987) Impacto de la pesquería de centolla y centollón sobre las poblaciones de mamíferos marinos de Magallanes, Chile. Ambiente Y Desarrollo 3(1-2) 111-119.

Carretta JV, Muto MM, Barlow J, Baker J, Forney KA, Lowry M (2002) U.S. Pacific marine mammal stock assessments: 2002. NOAA-TM NMFS-SWFSC-346, 286 pp.

Carretta JV, Chivers SJ (2004) Preliminary estimates of marine mammal mortality and biological sampling of cetaceans in California gillnet fisheries for 2003. NOAA Technical Memorandum SC/56/SM1, 20 pp.

Carretta JV, Price T, Petersen D, Read R (2004) Estimates of marine mammal, sea turtle and seabird mortality in the California drift gillnet fishery for swordfish and thresher shark, 1996-2002. Marine Fisheries Review 66(2): 2130.

Carretta JV, Forney KA, Muto MM, Barlow J, Baker J, Hanson B, Lowry M (2005) U.S. Pacific marine mammal stock assessments: 2004. NOAA-TM NMFS-SWFSC-375, 316 pp.

Carretta JV, Forney KA, Muto MM, Barlow J, Baker J, Hanson B, Lowry M (2006) U.S. Pacific marine mammal stock assessments: 2005. NOAA-TM NMFS-SWFSC-388, 317 pp.

Carretta JV, Forney KA, Muto MM, Barlow J, Baker J, Hanson B, Lowry M (2007a) U.S. Pacific marine mammal stock assessments: 2006. NOAA-TM NMFS-SWFSC-398, 312 pp.

Carretta JV, Forney KA, Lowry M, Barlow J, Baker J, Hanson B, Muto MM (2007b) U.S. Pacific marine mammal stock assessments: 2007. NOAA-TM NMFS-SWFSC-414, 316 pp.

Carretta JV, Enriquez L (2007) Marine mammal and sea turtle bycatch in the California/ Oregon thresher shark and swordfish drift gillnet fishery in 2006. Southwest Fisheries Science Center Administrative Report LJ-07-06, $9 \mathrm{pp}$.

Carretta JV, Forney KA, Lowry M, Barlow J, Baker J, Hanson B, Brownell B, Robbins J, Matilla DK, Ralls K, Muto MM, Lynch D, Carswell L (2009) U.S. Pacific marine mammal stock assessments: 2009. NOAA-TM NMFS-SWFSC453, $336 \mathrm{pp}$.

Carretta JV, Enriquez L (2009) Marine mammal and seabird bycatch in observed California commercial fisheries in 2007. Southwest Fisheries Science Center Administrative Report LJ-09-01, 12 pp.
Carretta JV, Forney KA, Oleson E, Martien K, Muto MM, Lowry MS, Barlow J, Baker J, Hanson B, Lynch D, Carswell L, Brownell B, Robbins J, Matilla DK, Ralls K, Hills MC (2011) U.S. Pacific marine mammal stock assessments: 2010. NOAA-TM-NMFS-SWFSC-476, 352 pp.

Carretta JV, Enriquez L (2012) Marine mammal and seabird bycatch in California gillnet fisheries in 2011. NOAA-TM-NMFS-SWFSC500, $14 \mathrm{pp}$.

Carretta JV, Wilkin SM, Muto MM, Wilkinson K (2013) Sources of human-related injury and mortality for U.S. Pacific West Coast marine mammal stock assessments, 2007 - 2011. NOAA-TM-NMFS-SWFSC-514, 87 pp.

Carretta JV, Enriquez L, Villafana C (2014) Marine mammal, sea turtle and seabird bycatch in California gillnet fisheries in 2012. NOAA-TM-NMFS-SWFSC-526, 16 pp.

Carretta JV, Muto MM, Wilkin S, Greenman J, Wilkinson $\mathrm{K}$, DeAngelis M, Viezbiche J, Lawson D, Rusin J, Jannot J (2015) Sources of humanrelated injury and mortality for U.S. Pacific west coast marine mammal stock assessments, 2009-2013. NOAA-TM-NMFSSWFSC-548, $108 \mathrm{pp}$.

Carretta JV, Oleson E, Baker J, Weller DW, Lang $A R$, Forney KA, Muto MM, Hanson B, Orr AJ, Huber H, Lowry MS, Barlow J, Moore JE, Lynch D, Carswell L, Brownell RL (2016) U.S. Pacific marine mammal stock assessments: 2015. NOAA-TM-NMFS-SWFSC-561, 419 pp.

Chilvers BL (2008) New Zealand sea lions Phocarctos hookeri and squid trawl fisheries: bycatch problems and management options. Endangered Species Research 5: 193-204.

Chilvers BL (2009) Foraging locations of a decreasing colony of New Zealand sea lions (Phocarctos hookeri). New Zealand Journal of Ecology 33: 106-113.

Chilvers BL (2015) Phocarctos hookeri (In: IUCN red list of threatened species 2015) IUCN. (https://dx.doi.org/10.2305/IUCN.UK. 2015-2.RLTS.T17026A1306343.en) Accessed 21January 2020.

Corcuera J, Monzon F, Crespo EA, Aguillar A, Raga JA (1994) Interactions between marine mammals and the coastal fisheries of Necochea and Claromecó (Buenos Aires Province, Argentina). Reports of the International Whaling Commission 15: 283-290. 
Crespo EA, Pedraza SN, Dans SL, Koen-Alonso M, Reyes LM, García NA, Coscarella M, Schiavini ACM (1997) Direct and indirect effects of the high seas fisheries on the marine mammal populations in the northern and central Patagonian coast. Journal of Northwest Atlantic Fishery Science 22: 189-207.

Crespo EA, Sepúlveda M, Szteren D (2012) Interacciones entre el lobo marino común y las actividades pesqueras y de acuicultura. In: Crespo EA, Oliva D, Dans S, Sepúlveda M (eds) Estado de situación del lobo marino común en su área de distribución. Editorial Universidad de Valparaíso, Valparaíso, pp. 66-110.

Dans SL, Koen-Alonso M, Crespo EA, Pedraza SN, García NA (2003) Interactions between marine mammals and high seas fisheries in Patagonia: an integrated approach. In: Gales N, Hindell M, Kirkwood R (eds) Marine mammals: fisheries, tourism and management issues. CSIRO, Collingwood, pp. 88-103.

Dayton PK, Thrush S, Coleman FC (2002) Ecological effect of fishing in marine ecosystems of the United States. Pew Oceans Commissions, Arlington, $44 \mathrm{pp}$.

Dau BK, Gilardi KVK, Gulland FM, Higgins A, Holcomb JB, Leger JS, Ziccardi MH (2009) Fishing gear-related injury in California marine wildlife. Journal of Wildlife Diseases 45(2): 355-362.

Dawson SM, Northridge S, Waples DM, Read A (2013) To ping or not to ping: the use of active acoustic devices in mitigating interactions between small cetaceans and gillnet fisheries. Endangered Species Research 19(3): 201-221.

De María M, Barboza FR, Szteren D (2014) Predation of South American sea lions (Otaria flavescens) on artisanal fisheries in the Rio de la Plata estuary. Fisheries Research 149: 69-73.

DeMaster DJ, Fowler CW, Perry SL, Richlen ME (2001) Predation and competition: the impact of fisheries on marine mammal over the next one hundred years. Journal of Mammalogy 82 : 641-651.

Denkinger J, Gordillo L, Monterro-Serra I, Murillo JC, Guevara N, Hirschfeld M, Fietz K, Rubianes F, Dan M (2015) Urban life of Galapagos sea lions (Zalophus wollebaeki) on San Cristobal Island, Ecuador: colony trends and threats. Journal of Sea Research 105: 10-14.
Doonan IJ (2000) Estimation of Hooker's sea lion, Phocarctos hookeri, captures in the southern squid trawl fisheries, 2000. New Zealand Fisheries Assessment Report 41, 11 pp.

Doonan IJ (2001) Estimation of Hooker's sea lion, Phocarctos hookeri, captures in the southern squid trawl fisheries, 2001. New Zealand Fisheries Assessment Report 67, 10 pp.

El-Mallakh RS, Hartman M (2018) The curious case of the missing face: death of California sea lion by Dungeness crab trap. International Journal of Aquatic Biology 6(4): 198-201.

Ferrari EJ, Schakner ZA, Villafana CA, Enriquez LS, Lawson DD (2015) Pilot study of underwater observations of interactions between harbor seals, California sea lions and cormorants with halibut trawl fisheries in Southern California. Aquatic Mammals 41(3): 333-340.

Ferrero RC, DeMaster DP, Hill PS, Muto MM, Lopez AL (2000) Alaska marine mammal stock assessments, 2000. NOAA Technical Memorandum NMFS-AFSC-119, 195 pp.

Forcada A, Valle C, Bonhomme P, Criquet G, Cadiou G, Lenfant P, Sánchez-Lizaso JL (2009) Effects of habitat on spillover from marine protected areas to artisanal fisheries. Marine Ecology Progress Series 379: 197-211.

Forney KA, Barlow J, Muto MM, Lowry M, Baker J, Cameron G, Mobley J, Stinchcomb C, Carretta JV (2000) U.S. Pacific mamal marine stock assessments: 2000. NOAA-TM-NMFS-SWFSC300, 276 pp.

Franco-Trecu V, Costa P, Abud C, Dimitriadis C, Laporta P, Passadore C, Szephegyi M (2009) By-catch of franciscana Pontoporia blainvillei in Uruguayan artisanal gillnet fisheries: an evaluation after a twelve-year gap in data collection. Latin American Journal of Aquatic Mammals 7(1-2): 11-22.

Franco-Trecu V, Drago M, Katz H, Machin E, Marín Y (2017) With the noose around the neck: marine debris entangling otariid species. Environmental Pollution 220: 985-989.

Gales NJ, Shaughnessy PD, Dennis TE (1994) Distribution, abundance and breedind cycle of the Australian sea lion, Neophoca cinerea (Mammalia: Pinnipedia). Journal of Zoology 234: 353-370. 
Gelatt T, Sweeney K (2016) Eumetopias jubatus (In: IUCN red list of threatened species 2016) IUCN. (https://dx.doi.org/10.2305/ IUCN.UK.2016-1.RLTS.T8239A45225749.en) Accessed 21 January 2020.

Gerber JA, Roletto J, Morgan LE, Smith DM, Gage LJ (1993) Findings in pinnipeds stranded along the central and northern California coast, 1984-1990. Journal of Wildlife Diseases 29(3): 423-433.

Geschke K, Chilvers, BL (2009) Managing big boys: a case study on remote anaesthesia and satellite tracking of adult male New Zealand sea lions (Phocarctos hookeri). Wildlife Research 36(8): 666-674.

Giglio VJ, Moura RL, Gibran FZ, Rossi LC, Banzato BM, Corsso JT, Pereira-Filho GH, Motta FS (2019) Do managers and stakeholders have congruent perceptions on marine protected area management effectiveness? Ocean \& Coastal Management 179. doi.org/ 10.1016/j.ocecoaman.2019.104865.

Goetz S, Wolff M, Stotz W, Villegas MJ (2008) Interactions between the South American sea lion (Otaria flavescens) and the artisanal fishery off Coquimbo, northern Chile. ICES Journal of Marine Science 65: 1739-1746.

Goldsworthy D (2015) Neophoca cinerea (In: IUCN Red List of Threatened Species 2015). IUCN. (https://dx.doi.org/10.2305/IUCN.UK. 2015-2.RLTS.T14549A45228341.en) Accessed 21 January 2010.

Goldstein T, Johnson SP, Phillips AV, Hanni KD, Fauquier DA, Gulland FMD (1999) Humanrelated injuries observed in live stranded pinnipeds along the central California coast 1986-1998. Aquatic Mammals 25(1): 43-51.

Goldsworthy SD, Page B, Shaughnessy PD, Linnane A (2010) Mitigating seal interactions in the SRLF and the gillnet sector SESSF in South Australia. Report to the Fisheries Research and Development Institute. South Australian Research and Development Institute (Aquatic Sciences), Adelaide. SARDI Publication No.F2009/000613-1.SARDI Research Report Series 405, 213 pp.

González A, Vega R, Yáñez E (2015) Operational interactions between the South American sea lion Otaria flavescens and purse seine fishing activities in northern Chile. Revista de Biología Marina y Oceanografía 50(3): 479-489.
Gormley AM, Slooten E, Dawson S, Barker RJ, Rayment W, du Fresne S, Bräger S (2012) First evidence that marine protected areas can work for marine mammals. Journal of Applied Ecology 49: 474-480.

Hamer DJ, Ward TM, Shaughnessy PD, Clark SR (2011) Assessing the effectiveness of the Great Australian Bight Marine Park in protecting the endangered Australian sea lion Neophoca cinerea from bycatch mortality in shark gillnets. Endangered Species Research 14: 203-216.

Hamer DJ, Goldsworthy SD, Costa DP, Fowler SL, Page B, Sumner MD (2013) The endangered Australian sea lion extensively with and regularly becomes by-catch in demersal shark gill-nets in South Australian shelf waters. Biology Conservation 157: 386400.

Hamilton S, Baker GB (2014) Current bycatch levels in Auckland Islands trawl fisheries unlikely to be driving New Zealand sea lion (Phocarctos hookeri) population decline. Aquatic Conservation 26: 121-133.

Hanni KD, Pyle P (2000) Entanglement of pinnipeds in synthetic materials at South-east Farallon Island, California, 1976-1998. Marine Pollution Bulletin 40(12): 1076-1081.

Harcourt R, Aurioles D, Sanchez J (1994) Entanglement of California sea lions at Los Islotes, Baja California Sur, Mexico. Marine Mammal Science 10: 122-125.

Harwood J (1983) Interactions between marine mammals and fisheries. Advanced Applied Biology 8: 189-214.

Heery E, Bellmann MA, Majewski J (2010) Estimated bycatch of marine mammals, seabirds and sea turtles in the 2002-2008 U.S. west coast commercial groundfishfishery. West Coast Groundfish Observer Program. NWFSC, 2725 Montlake Blvd E., Seattle, WA 98112, $104 \mathrm{pp}$.

Hipfner JM, Lok EK, Jardine C, Studholme K, Lebeau AC, Wright KG, Trefry SA, Drever MC, Jones $G$ (2018) Beach-cast debris surveys on Triangle Island, British Columbia, Canada indicate the timing of arrival of 2011 Tokohu tsunami debris in North America. Marine Pollution Bulletin 136: 407-413. 
Hückstädt LA, Antezana T (2003) Behaviour of the southern sea lion (Otaria flavescens) and consumption of the catch during purseseining for jack mackerel (Trachurus symmetricus) off central Chile. Journal of Marine Science 60: 1003-1011.

Hückstädt LA, Krautz T (2004) Interaction between southern sea lions Otaria flavescens and jack mackerel Trachurus symmetricus commercial fishery off central Chile: a geoestatistical approach. Marine Ecology Progress Series 282: 285-294.

Jones MM (1995) Fishing debris in the Australian marine environment. Marine Pollution Bulletin 30: 25-33.

Julian F, Beeson M (1998) Estimates of marine mammal, turtle and seabird mortality for two California gillnet fisheries: 1990-1995. Fisheries Bulletin 96: 271-284.

Kaschner K, Pauly D (2005) Competition between marine mammals and fisheries: food for thought. In: Salem DJ, Rowan AN (ed) The State of the Animals III. Humane Society Press, Washington, pp. 95-117.

Keledjian AJ, Mesnick S (2013) The impacts of EI Niño conditions on California sea lion (Zalophus californianus) fisheries interactions: predicting spatial and temporal hotspots along the California coast. Aquatic Mammals 39(3): 221-232.

Koen-Alonso MK, Crespo EA, Pedraza SN, García NA, Coscarella MA (2000) Food habits of the South American sea lion, Otaria flavescens, off Patagonia, Argentina. Fisheries Bulletin 98(2): 250-263.

Kovacs KM, Aguilar A, Aurioles D, Burkanov V, Campagna C, Gales N (2012) Global threats to pinnipeds. Marine Mammal Science 28(2): 414436.

La Torriente A, Quiñones RA, Miranda-Urbiana DA, Echevarría F (2010) South American sea lion and spiny dogfish predation on artisanal catches of southern hake in fjords of Chilean Patagonia. ICES Journal of Marine Science 67: 294-303.

Laist DW (1997) Impacts of marine debris: entanglement of marine life in marine debris including a comprehensive list of species with entanglement and ingestion records. In: Coe JM, Rogers DB (ed) Marine Debris: Sources, Impacts and Solutions. Springer Series on Environmental Management, New York, pp. 99-140.
Lavigne DM (2003) Marine mammals and fisheries: the role of science in the culling debate. In: Gales N, Hindel M, Kirkwood R (ed) Marine Mammals: Fisheries, Tourism and Management Issues. SCIRO publications Melbourne, pp. 31-47

Loughlin TR, Consiglieri L, Delong RL, Actor AT (1983) Incidental catch of marine mammals by foreign fishing vessels, 1978-81. Marine Fisheries Review 45: 44-49.

Loughlin TR, Rugh DJ, Fiscus CH (1984) Northern sea lion distribution and abundance: 1956-1980. Journal of Wildlife Management 48: 729-740.

Loughlin TR (1986) Assessment of net entanglement on Northern sea lions in the Aleutian Islands 25 June - 15 July 1985. National Marine Mammal Laboratory, Northwest and Alaska Fisheries Center, NMFS, NOAA, 50 pp.

Loughlin TR, Nelson R (1986) Incidental mortality of northern sea lions in Shelikof Strait, Alaska. Marine Mammal Science 2(1): 14-33.

Machado R, Ott PH, Moreno IB, Danilewicz D, Tavares M, Crespo EA, Siciliano S, Oliveira LR (2016) Operational interactions between South American sea lions and gillnet fishing in southern Brazil. Aquatic Conservation and Marine Freshwater Ecosystems 26(1): 108-120.

Machado R, Oliveira LR, Montealegre-Quijano S (2015) Incidental catch of South American sea lion in a pair trawl off southern Brazil. Neotropical Biology and Conservation 10(1): 4347.

Magera AM, Mills Flemming JE, Kaschner K, Christensen LB, Lotze HK (2013) Recovery trends in marine mammal populations. PLoS ONE 8(10). .doi.org/10.1371/journal.pone. 0077908.

Majluf $P$, Babcock EA, Riveros JC, AriasSchreiber M, Alderete W (2002) Catch and bycatch of sea birds and marine mammals in the small-scale fishery of Punta San Juan, Peru. Conservation Biology 16(5): 1333-1343.

Maniscalco JM, Wynne K, Pitcher KW, Hansob MB, Melin SR, Atkinsin S (2004) The occurrence of California sea lions (Zalophus californianus) in Alaska. Aquatic Mammals 30(3): 427-433. 
Manly BFJ, Seyb A, Fletcher DJ (2002) Bycatch of sea lions (Phocarctos hookeri) in New Zealand fisheries, $1987 / 88$ to $1995 / 96$, and observer coverage. Doc Science Internal Series 42, Wellington, Department of Conservation, 21 pp.

Manly BFJ (2007) Incidental take and interactions of marine mammals and birds in the Kodiak Island salmon set gillnet fishery, 2002 and 2005. Final report to NMFS Alaska Region, $221 \mathrm{pp}$.

Manville AM (1990) A survey of plastics on western Aleutian Island beaches and realted wildlife management. In: Shomura RS, Godfrey ML (ed) Proceedings of the Second International Conference on marine debris, U.S. Dep. Commer., NOAA Tech. Memo., NMFS, Honolulu, Hawaii, pp. 349-362.

Maunder MN, Starr PJ, Hilborn R (2000) A Bayesian analysis to estimate loss in squid catch due to the implementation of a sea lion population management plan. Marine Mammal Science 16(2): 413-426.

Maravilla-Chávez MO, Hernández-Vázquez S, Zavala-González A, Ortega-Rubio A (2006) Reduction of the impact produced by sea lions on the fisheries in Mexico. Journal of Environmental Biology 27(4): 629-631.

Mawson PR, Coughran DK (1999) Records of sick, injured and dead pinnipeds in Western Australia 1980-1996. Journal of the Royal Society of Western Australia 82: 121-128.

McAuley R, Simpfendorfer C (2003) Catch composition of the Western Australian temperate demersal gillnet and demersal longline fisheries, 1994-1999. Fisheries Research Report 146, 78 pp.

Miller DJ, Herder MJ, Scholl JP (1983) California marine-mammal fishery interaction study, 1979-1981. NMFS Southwest Fisheries Center, Administrative Report LJ-83-13C, 233 pp.

Moore E, Lyday S, Roletto J, Litle K, Parrish JK, Nevins $H$, Harvey J, Mortenson J, Greig D, Piazza M, Hermance S, Lee D, Adams D, Allen S, Kell S (2009) Entanglement of marine mammals and seabirds in Central California and the North-west coast of the United States 2001-2005. Marine Pollution Bulletin 58: 10451051.
Mora-Pinto DM, Muñoz-Hincapié MF (1995) Marine mammal mortality and strandings along the Pacific coast of Colombia. Reports of the International Whaling Commission 45: 427-429.

Moreno CA, Hucke-Gaete R, Arata J (2003) Interacción de la pesquería del bacalao de profundidad con mamíferos y aves marinas. Informe Final Proyecto FIP No. 2001-31, 199 pp.

Myers RA; Worm B (2003) Rapid worldwide depletion of predatory fish communities. Nature 423: 280-283.

National Seal Strategy Group (NSSG), Stewardon C (2007) National assessment of interactions between humans and seals: fisheries, aquaculture and tourism. Canberra, Department of Agriculture, Fisheries and Forestry, $149 \mathrm{pp}$.

Oporto J, Mercado C, Brieva L (1991) Conflicting interactions between coastal fisheries and pinnipeds in southern Chile. Report on the Benguela Ecology Programme Workshop on Seal-Fishery Biological Interactions, University of Cape Town, South Africa, Working paper BEP/SW91/R8.

Páez-Rosas D, Guevara N (2017) Management strategies and conservation status of Galapagos sea lion populations at San Cristobal Island, Galapagos, Ecuador. In: Alava JJ (ed) Tropical Pinnipeds: Bio-ecology, Threats and Conservation. Taylor and Francis Group, Florida, pp. 159-175.

Page B, McKenzie J, Mclntosh R, Baylis A, Morrissey A, Calvert N, Haase T, Berris M, Bowie D, Shaughnessy PD, Goldsworthy SD (2004) Entanglement of Australian sea lions and New Zealand fur seals in lost fishing gear and other marine debris before and after Government and industry attempts to reduce the problem. Marine Pollution Bulletin 49: 33-42.

Passadore C, Szephegyi M, Domingo A (2008) Presencia de mamíferos marinos y captura incidental en la flota uruguaya de palangre pelágico. Collective Volumes of Scientific Papers ICCAT 62(6): 1851-1857.

Passadore C, Domingo A, Secchi ER (2015) Analysis of marine mammal bycatch in the Uruguayan pelagic longline fishery operating in Southwestern Atlantic Ocean. ICES Journal of Marine Science 75: 1637-1652. 
Páez H (2005) Situación de la administración del recurso lobos y leones marinos en Uruguay. In: Menafra R, Gallgo LR, Scarabina F, Conde D (eds) Bases para la Conservación y el Manejo de la Costa Uruguaya. Vida Silvestre Uruguay Montevideo, pp. 557-581.

Pauly D, Zeller D (2016) Catch reconstructions reveal that global marine fisheries catches are higher than reported and declining. Nature Communications 7:10244.

Perez MA (2003) Compilation of marine mammal incidental take data from the domestic and joint venture groundfish fisheries in the U.S. EEZ of the North Pacific, 1989-2001. U.S. Dep. Commer., NOAA Tech. Memo, NMFS-AFSC-128, 145 pp.

Perez MA (2006) Analysis of marine mammal bycatch data from the trawl, longline and pot groundfish fisheries of Alaska, 1998-2004, defined by geographic area, gear type and catch target groundfish species. U.S. Dep. Commer., NOAA Tech. Memo. NMFS-AFSC-167, $194 \mathrm{pp}$.

Perez MA, Loughlin TR (1991) Incidental catch of marine mammals by foreign and joint venture trawl vessels in the U.S. EEZ of the North Pacific, 1973-88. U.S. Dep. Commer., NOAA Technical Report NMFS 104, 57 pp.

Perrin WF (1991) What can be done about conflicts between marine mammals and fisheries? Symposium "Present status of marine mammals in Taiwan", National Taiwan Ocean University, Keelung, pp. 21-35.

Petry MV, Fonseca VSS (2001) Mamíferos marinhos encontrados mortos no litoral do Rio Grande do Sul de 1997 a 1998. Acta Biologica Leopoldinense 23(2): 225-235.

Plagányi EE, Buttenworth DS (2009) Competition with fisheries. In: Perrin WF, Würsig B, Thewissen HGM (ed) 2nd edition. Encyclopedia of marine mammals. Academic Press, pp. 269-275.

Phillips CD, Bickham JW, Patton JC, Gelatt TS (2009) Systematics of Steller sea lions (Eumetopias jubatus): subspecies recognition based on concordance of genetics ad morphometrics. Occasional Papers 283: 1-15.
Przbylski CB, Monteiro-Filho ELA (2001) Interação entre pescadores e mamíferos marinhos no litoral do Estado do Paraná Brasil. Biotemas 14(2): 141-156.

Ramos KL (2018) Conservação de pinípedes em Áreas Marinhas Protegidas: análise dos conflitos com a pesca. UESC, llhéus, 138 pp.

Raum-Suryan KL, Jemison LA, Pitcher KW (2009) Entanglement of Steller sea lions (Eumetopias jubatus) in marine debris: identifying causes and finding solutions. Marine Pollution Bulletin 58: 1487-1495.

Read AJ (2005) Bycatch and depredation. In: Reynolds JE, Perrin WF, Reeves RR, Montgomery S, Ragen TJ (ed) Marine mammal research: conservation beyond crisis. ohns Hopkins University Press, Baltimore, pp. 5-17.

Read AJ, Drinker P, Northridge S (2006) Bycatch of marine mammals in U.S. and global fisheries. Conservation Biology 20(1): 163-169.

Read AJ (2008) The looming crisis: interactions between marine mammals and fisheries. Journal of Mammology 89(3): 541548.

Reeves RR, McClellan K, Werner TB (2013) Marine mammal bycatch in gillnet and other entangling net fisheries, 1990 to 2011. Endangered Species Research 20: 71-97.

Reyes P, Hucke-Gaete R, Torres-Florez JP (2013) First observations of operational interactions between bottom-trawling fisheries and South American sea lion, Otaria flavescens, in south-central Chile. Journal of Marine Biological Association of the United Kingdom 93(2): 489-494.

Robertson BC, Chilvers BL (2011) The population decline of the New Zealand sea lion Phocarctos hookeri: a review of possible causes. Mammal Review 41(4): 253-275.

Rosas FCW, Pinedo MC, Marmontel M, Haimovici M (1994) Seasonal movements of the South American sea lion (Otaria flavescens, Shaw) of the Rio Grande do Sul coast, Brazil. Mammalia 58(1): 51-59.

Seco Pon JPS, García G, Copello S, Morettini A, Lértora HP, Pedrana J, Mauco L, Favero M (2012) Seabird and marine mammal attendance in the Chub mackerel Scomber japonicus semi-industrial Argentinian purse seine fishery. Ocean and Coastal Management 64: 56-66. 
Seco Pon JP, Copello S, Morettini A, Lértora HP, Bruno I, Bastida J, Mauco J, Favero M (2013) Seabird and marine-mammal attendance and by-catch in semi-industrial trawl fisheries in near-shore waters of northern Argentina. Marine Freshwater Research 64(3): 237-248.

Segura AM, Delgado EA, Carranza A (2008) La pesquería de langostino em Punta del Diablo (Uruguay): um primer acercamiento. PANAMJAS 3(3): 232-236.

Sepúlveda M, Pérez MJ, Sielfeld W, Oliva D, Durán LR, Rodríguez L, Araos V, Buscaglia M (2007) Operational interactional between South American sea lions Otaria flavescens and artisanal (small-scale) fishing in Chile: results from interview surveys and on-board observations. Fisheries Research 83: 332-340.

Sepúlveda M, Martínez T, Oliva D, Couve $P$, Pavez G, Navarro C, Stehlik M, René Durán L, Luna-Jorquera $G$ (2018) Factors affecting the operational interaction between the South American sea lion and the artisanal gillnet fishery in Chile. Fisheries Research 201: 147152.

Shaughnessy P, Kirkwood R, Cawthorn M, Kemper C, Pemberton D (2003) Pinnipeds, cetaceans and fisheries in Australia: a review of operational interactions. In: Gales N, Hindell M, Kirkwood R (ed) Marine mammals: fisheries, tourism and management issues. CSIRO, Collingwood, pp. 136-152.

Shester GG, Micheli F (2011) Conservation challenges for small-scale fisheries: bycatch and habitat impacts of traps and gillnets. Biological Conservation 144: 1673-1681.

Smith MH, Baird SJ (2007) Representativeness of past observer coverage and future coverage required for estimation of New Zealand sea lion (Phocarctos hookeri) captures in the SQU 6T fishery. New Zealand Fisheries Assessment Report 2005/5, 39 pp.

Smith MH, Baird SJ (2011) Predicted incidental captures of New Zealand sea lions (Phocarctos hookeri) in the Auckland Islands SQU 6T squid trawl fishery for 1995 to 2006. New Zealand Aquatic Environmental and Biodiversity Report 71, 34 pp.

Stewart BS, Yochem PK (1987) Entanglement of pinnipeds in synthetic debris and fishing net and line fragments at San Nicolas and San Miguel Islands, California, 1978-1986. Marine Pollution Bulletin 18: 336-339.
Swartz W, Sala E, Tracey S, Watson R, Pauly D (2010) The spatial expansion and ecological footprint of fisheries (1950 to present). PLoS ONE 5(12). doi:10.1371/journal.pone.0015143.

Szteren D, Páez E (2002) Predation by southern sea lions (Otaria flavescens) on artisanal fishing catches in Uruguay. Marine Freshwater Research 53: 1161-1167.

Szteren D (2006) Predation of Otaria flavescens over artisanal fisheries in Uruguay: opportunism or prey selectivity? LAJAM 5(1): 29-38.

Szteren D, Lezama C (2006a) Southern sea lions and artisanal fisheries in Piriápolis, Uruguay: interactions in 1997, 2001, and 2002. In: Trites AW, Atkinson SK, DeMaster DP, Fritz LW, Gelatt TS; Rea LD; Wynne KM (eds) Sea lions of the world. Alaska Sea Grant College Program, Fairbanks, pp. 591-604.

Szteren D, Lezama C (2006b) Interacciones entre lobos marinos y pesca artesanal en la costa de Uruguay. In: Menafra R, RodríguezGallego L, Scarabino F, Conde D (eds) Bases para la conservación y el manejo de la costa uruguaya. Vida Silvestre, Montevideo, pp. 321328.

Thompson FN, Abraham ER (2009) Estimation of the capture of New Zealand sea lions (Phocarctos hookeri) in trawl fisheries from 1995-96 to 2006-07. New Zealand Aquatic Environmental and Biodiversity Report 41, 31 pp.

Thompson FN, Berkenbusch K, Abraham ER (2013). Marine mammal bycatch in New Zealand trawl fisheries, 1995-96 to 2010-11. New Zealand Aquatic Environment and Biodiversity Report 15, 73 pp.

Thompson FN, Berkenbusch K, Berizhoff-Law M (2015) Reported New Zealand sea lion (Phocarctos hookeri) captures in commercial trawl fisheries, 1991-92 to 2012-13. New Zealand Aquatic Environmental and Biodiversity Report 145, 43 pp.

Trillmich F (2015) Zalophus wollebaeki (In: IUCN Red List of Threatened Species 2015). IUCN. (https://dx.doi.org/10.2305/IUCN.UK. 2015-2.RLTS.T41668A45230540.en). Accesses 28 January 2020. 
Trites A.W, Larkin PA (1992) The status of Steller sea lion populations and the development of fisheries in the Gulf of Alaska and Aleutian Islands. Report of the Pacific States Marine Fisheries Commission pursuant to NOAA award No. NA17FD0177, 143 pp.

Vaz-Ferreira R (1981) South American sea lion Otaria flavescens (Shaw). In: Ridgway $S$, Harrison R (eds) Handbook of marine mammals. Academic Press, New York, pp. 39-66.

Warlick AJ, Duffield DA, Lambourn DM, Jeffries SJ, Rice JM, Gaydos JK, Huggins JL, Calambokidis J, Lahner LL, Olson J, D'Agnese E, Souze V, Elsby A, Norman SA (2018) Spatiotemporal characterization of pinniped strandings and human interaction cases in the Pacific Northwest, 1991-2016. Aquatic Mammals 44(3): 299-318.

Weise MJ, Harvey JT (2005) Impact of the California sea lion (Zalophus californianus) on salmon fisheries in Monterey Bay, California. Fisheries Bulletin 103(4): 685-696.

Wickens PAA (1995) Review of operational interactions between pinnipeds and fisheries. FAO Fisheries Technical Paper 346, 86 pp.

Wilkinson I, Burgess J, Cawthorn M (2003) New Zealand sea lions and squid: managing fisheries impacts on a threatened marine mammal. In: Gales N, Hindell M, Kirkwood R (eds) Marine mammals: fisheries, tourism and management issues. CSIRO, Collingwood, pp. 192-206.
Woodley TH, Lavigne DM (1991) Incidental capture of pinnipeds in commercial fishing gear. IMMA Inc. Technical Report No. 91-01, pp. 1-35.

Wynne KM, Hicks D, Munro N (1992) 1991 marine mammal observer program for the salmon driftnet fishery of Prince William Sound, Alaska. Annual Report NMFS/NOAA, Alaska Region, Office of Marine Mammals, Juneau, Alaska, pp. 53.

Zavala-González A, Mellink E (1997) Entanglement of California sea lions, Zalophus californianus californianus, in fishing gear in the central-northern part of the Gulf of California, Mexico. Fisheries Bulletin 95-180-184.

Zimmerhackel JS, Schuhbauer AC, Usseglio P, Heel LC, Salinas-de-León P (2015) Catch, bycatch and discards of the Galapagos Marine Reserve small-scale handline fishery. Peer J 3: e995.
Received: 03 February 2020

Accepted: 25 May 2020

Published: 05 June 2020 